\title{
Fen Bilgisi Öğretmenlerinin Sorgulayıcı Yaklaşıma Uygun Laboratuvar Kullanım Yeterlikleri ve Karşılaşılan Sorunlar ${ }^{1}$
}

\author{
Harun ÇELIKK \\ Kırıkkale Üniversitesi \\ haruncelik@kku.edu.tr \\ Oğuzhan KÖKEN \\ Milli Eğitim Bakanlığı \\ oguzhankk2@gmail.com \\ Bilge KANAT \\ Milli Eğitim Bakanlığ1 \\ bilgekanat71@gmail.com
}

Gönderilme Tarihi: 20/06/2021 Kabul Tarihi: 31/07/2021

Yayınlanma Tarihi: 31/07/2021

\begin{tabular}{|c|c|}
\hline Makale Bilgileri & ÖZET \\
\hline $\begin{array}{l}\text { Anahtar Kelimeler: } \\
\text { Araştırmacı- } \\
\text { Sorgulayıcı } \\
\text { Yaklaşım, } \\
\text { Fen Laboratuvarı, } \\
\text { Fen Öğretimi } \\
\text { Yeterlikleri, } \\
\text { Laboratuvar } \\
\text { Uygulamaları }\end{array}$ & $\begin{array}{l}\text { Bu araştırmada, fen bilgisi öğretmenlerinin günümüz öğretim anlayışına göre } \\
\text { laboratuvarların uygulanabilirliğine ilişkin sorunları, görüşleri ve yeterlikleri } \\
\text { incelenmiştir. Araştırmada, karma araştırma yöntemlerinden sıralı açımlayıcı desen } \\
\text { kullanılmıştır. Çalışmanın nicel araştırma boyutunda tarama yöntemi, nitel } \\
\text { araştırma ise fenomenoloji (olgu bilimi) deseni kullanılmıştır. Araştırmada, fen } \\
\text { bilimleri öğretmenlerinden veriler toplamak amacıyla laboratuvar yeterlik ölçeği ve } \\
\text { yarı yapılandırılmış görüş formu kullanılmıştır. Bununla birlikte kontrol listesi ile } \\
\text { laboratuvarların fiziki ve güvenlik durumunun yanı sıra öğretim programına } \\
\text { uyumluluğu da ele alınmıştır. Verilerin analizinde, nicel verilerde bir istatistik paket } \\
\text { programından yararlanılmıs ve betimsel analizler yapılmıştır. Nitel veriler ise ise } \\
\text { içerik analizi ile çözümlenmiştir. Araştırmanın sonucuna göre, bazı öğretmenlerin } \\
\text { laboratuvarı aktif olarak kullandıklarını ve kendilerini bu kapsamda yeterli } \\
\text { gördükleri belirlenmiştir. Laboratuvar çalışmalarına yönelik yeterlik düzeyi kadın } \\
\text { öğretmenlerin lehine oluşmuştur. Öğretmenlerin çoğu laboratuvar malzemelerinin } \\
\text { yeterli olduğu yönünde görüş belirtmiş ancak sınıf mevcudunun sorun yaşattığını } \\
\text { ve olası bir güvenlik sorununda laboratuvar kullanımını azaltmayı düşündüklerini } \\
\text { ifade etmişlerdir. Laboratuvar uyumluluğunu araştırmak için kullanılan kontrol } \\
\text { listesine göre öğretmenler, laboratuvarların fiziki konumunun kullanıma ve } \\
\text { gündelik deneylere uygunluğuna yönelik olumlu ifadeler kullanmıslardır. Fen } \\
\text { bilgisi öğretmenlerinin laboratuvarların daha fazla kullanımı konusunda, öğretmen } \\
\text { motivasyonunu arttırabilecek teşvikler yanısıra bağımsı ders olarak } \\
\text { planlanabileceği gibi çözüm önerileri dikkat çekmektedir. }\end{array}$ \\
\hline
\end{tabular}

${ }^{1} \mathrm{Bu}$ araştırma Doç. Dr. Harun Çelik danışmanlığında yürütülen Bilge Kanat tarafından 2018 yılında tamamlanan yüksek lisans tezinden üretilmiştir.

Çelik, H., Köken, O., \& Kanat, H. (2021). Fen bilgisi öğretmenlerinin sorgulayıcı yaklaşıma uygun laboratuvar kullanım yeterlikleri ve karşılaşılan sorunlar. Gazi Eğitim Bilimleri Dergisi, 7(2), 196223. https://dx.doi.org/10.30855/gjes.2021.07.02.005

Dergi Web Sayfası: http://dergipark.gov.tr/gebd 


\section{Science Teachers' Competences in Using Laboratory Appropriate Inquiry Approach and Problems Encountered}

\begin{tabular}{ll}
\hline \hline Article Info & ABSTRACT \\
\hline Keywords: & In this study, science teachers' views, problems encountered and competencies \\
Inquiry Approach, & regarding the applicability of laboratories according to today's teaching approach \\
Laboratory & were examined. Sequential explanatory design, one of the mixed research methods, \\
Applications, & was used in the research. The quantitative research design of the study was used in \\
Science Laboratory, & the descriptive method, while the qualitative research was used in the \\
Science Teaching & phempenenology (phenomenology) design. In this study; laboratory proficiency scale \\
and semi-structured opinion form were used to collect data from science teachers. & And in addition, the physical and security conditions of the laboratories as well as \\
their compliance with the curriculum were evaluated through the checklist. In the \\
analysis of the data, the SPSS 23.0 package program was used for the quantitative \\
data and descriptive analysis was performed. Content analysis technique was used \\
in qualitative data analysis. According to the results of the study, some teachers \\
stated that they use the laboratory actively and they consider themselves sufficient \\
in this context. When examined in terms of gender, the level of competence of women \\
in laboratory studies is higher than that of men, and the result was determined within \\
the scope of the study. It is among the results of the study that teachers feel \\
inadequate in having maintenance and repair knowledge skills. In addition, most of \\
the teachers stated that the laboratory equipment was sufficient, but they stated that \\
the class size was a problem and they thought to reduce the use of the laboratory in \\
case of a possible safety problem. As a result of the laboratory control questionnaire, \\
the teachers made positive statements regarding the suitability of the physical \\
location of the laboratories for use and daily experiments. According to the data \\
obtained on the regulations and the incentives that can increase the teacher \\
motivation in the use of the laboratory, the general view is that there should be \\
separate additional courses for the laboratory.
\end{tabular}

\section{GİRIŞ}

Bilimin hızla geliştiği çağımızda fen eğitimi büyük önem taşımakta ve bu doğrultuda fen eğitimi farklı öğretim teknik ve yöntemlerle geliştirilmeye/desteklenmeye çalışılmaktadır. Bu kapsamda, fen bilimlerini diğer bilim dallarından ayıran en önemli özellik; deneye, gözleme ve keşif yapmaya önem vermesi, öğrencilerin soru sorma, araştırma yapma becerilerini geliştirmesi ve öğrencilere hipotez kurabilme ve ortaya çıkan sonuçları yorumlayabilme imkânı sağlamasıdır (Yazıcı ve Özmen, 2015). Bu nedenle fen öğretiminde laboratuvarlar bilimsel deneyler, gösteriler ve sorgulamalar için tasarlanmış ve bu doğrultuda önem kazanmıştır (Kwok, 2015). Laboratuvarlar öğrencinin kendi yaşantıları yoluyla bilgi, beceri, tutum ve deneyim kazanmalarını sağlayan ortamlardır (Karamustafaoğlu ve Yaman, 2006). Laboratuvar, bazı soyut kavram veya konuların bizzat denendiği laboratuvarlar, öğrencilerin psikomotor becerilerini kullanarak görsel zekaya yönelmenin gerçekleştiği, belirli sınırları olan kontrol edilebilir bir ortamdır. Farklı öğrenme ürünlerine vurgu bakımından laboratuvar, bilginin ürüne yansıdığı, problemin ve hipotezlerin tanımlandığı, birçok gözlem veya soyut algılamalar sonucu zihinde 
oluşan soruların somutlaştırılarak anlam kazandığı (Güneş, Şener, Topal ve Can, 2013), özel bir ortamdir.

Ayrıca doğru ve etkili bir şekilde yapılan laboratuvar uygulamaları öğrencilerin fen konularına karşı olumlu tutum geliştirmelerini sağlamasının yanı sıra, öğrencilerin problem çözme ve psikomotor becerilerinin gelişmesine, kendi bilgilerini oluşturmalarına da önemli katkılar sağlamaktadır (Böyük, Demir ve Erol, 2010). Yapılan tespitler doğrultusunda laboratuvarlar, emniyet ve güvenliğin sağlandığı ölçüde, bireyde bilişsel, duyuşsal, psikomotor, bilimsel ve yaşam becerilerinin etkin ve bütünleşik olarak kullanılmasına imkan veren tematik fen öğrenme atölyeleri olarak görülebilir (Çelik, 2018).

\section{Sorgulayıcı Yaklaşım ve Fen Laboratuvarları}

Günümüzde, 21. yüzyıl becerilerinin bireye kazandırılması noktasında aktif öğrenme sürecine verdiği destekle birlikte fen öğrenmenin ve öğretiminin merkezinde görülen laboratuvar aktiviteleri, sorgulayıcı yaklaşımın uygulamasını destekleyen öğrenme ortamları olarak dikkat çekmektedir. (Çelik, 2018). Sorgulamaya dayalı öğrenme, öğrencilerin, üst düzey düşünme yetisini geliştirme sürecinde sorgulamayı kullanan; süreci soru sormaya, eleştirel düşünmeye ve problem çözmeye dayanan, öğrenciyi merkeze alarak yaparak yaşayarak öğrenmeyi destekleyen bir yaklaşımdır (Branch ve Solowan, 2003). Laboratuvar ortamı da bireyde eleştirel düşünmeyi, bilimi anlamayı ve üretmeyi öğretir (Akdeniz, Azar ve Çepni, 1999). Millar (2004) fen laboratuvarların; konuya ilişkin yeterliliği geliştirmek, bilimsel akıl yürütme yollarını geliştirmek, deneysel çalışmanın bilimsel anlayışıı kavramak, pratik beceriler geliştirmek, bilimin doğasını anlamak, fen öğrenimine ve bilime olan ilgiyi artırmak, takım çalışması alışkanlığını kazanmak doğrultusunda fen öğretimine ve bireye değerli kazanımlar sağladığına işaret etmektedir. Öğrenme yaklaşımlarında sorgulayıcı bir veri toplama aracı olarak deney ve gözlemler yoluyla öğrenilen fen derslerinin öğrenci motivasyonunu artırdığı ve onları fen öğrenmeye karşı istekli hale getirdiği de ileri sürülen bilgiler arasındadır. Böyle bir öğrenme ortamında öğrencilerin yeni düşünceler üreterek eleştirel düşünmeyi kazanabilmesi sorgulayıcı öğrenme ile gerçekleşir (Duban, 2014). Sorgulamaya dayalı öğrenme etkinliklerinde öğretmen rehber, öğrenci ise aktif olduğu için öğrenme süreci artan motivasyonla birlikte eğlenceli, kazanımlar ise kalıcı olmaktadır.

Laboratuvarlarda yapılan öğretim etkinlikleri öğrencinin aktif olmasına göre sınıflandırıldığında; teknik beceriler kazanmak, bilimsel bilgiyi doğrulamak, bilgiyi tümevarımsal edinmek ve bilimsel süreç becerilerini geliştirmek amaçlı planlandığı görülmektedir. Bilimsel süreç becerilerine yönelik kazanımlar ise araştırmaya/buluşa dayalı ve bütünleştirici-yapılandırmacı bir tasarımla gerçekleşebilmektedir (Çelik, 2018). Laboratuvara yönelik bu yaklaşımlar bir sayı doğrultusunda gösterilirse bir ucunda doğrulama/ispat türünde 
deneyler diğer ucunda ise açık-uçlu laboratuvar deneyleri temsili olarak yer alabilir. Fen Bilimleri Dersi Öğretim Programı (MEB, 2013; 2018) ve fen eğitimi literatürü incelendiğinde laboratuvar etkinliklerinin yapılandırılmış, rehberli ve açık-uçlu araştırmayıcı - sorgulayıcı bir öğrenme yaklaşımı ile ilköğretim düzeyinde planlanması gerektiği görülmektedir (Duban, 2014; Çelik, 2018; Köseoğlu ve Tümay, 2015). Bu durum fen bilimleri dersinde deneysel etkinliklerde mikroskoba yer veren bir benzetimle modellenebilir. Temel eğitim düzeyinde ( 3 ve 4 . sinıflarda) mikroskop kullanımının sorumluluğu öğretmende iken öğrencinin inceleme şansı bulduğu ve yine öğretmenin sorgulama süreçlerini kullandığı bir öğrenme ortamı ile tasvir edilebilir. Burada teknik beceriler yaklaşımı konusunda öğrencilerin yeterli konuma gelmediği dikkate alınmalıdır. Ortaokul fen bilimleri dersinde ise 5. ve 6. sınıflarda öğretmenin grup çalışmasında rehberlik yapabilmek için öğrencilerden uzaklaşılmadan mikroskobun öğrenciye teslim edildiği bir betimleme yerinde olacaktır. 7. ve 8 . sınıflarda ise hem bilimsel süreç becerileri hem de yaşam becerilerinin gelişimi için öğrencinin etkinliği daha serbest düzenleyebileceği ve de güvenlik şartları içinde olası hata yapma fırsatının sağlanabileceği açık-uçlu araştırmacı sorgulayıcı laboratuvar etkinlikleri olarak modellenebilir.

Eğitimin önemli bir paydaşı olarak fen bilgisi öğretmenlerini laboratuvar konusunda büyük bir sorumluluk beklemektedir. Buna rağmen öğretim programlarında laboratuvar uygulamaları ile bağlantılı kazanımlar hedeflenmiş olsa da öğretim programının uygulayıcısı öğretmenler tarafından yapılamadığı veya öğrencilere yaptırılmadığı ve deney yapmak yerine kazanımlara sadece anlatılarak ulaşılmaya çalışıldığı işaret eden araştırmalar mevcuttur (Uluçınar, Cansaran ve Karaca, 2004). Bu doğrultuda yapılan literatür taraması sonucunda; derslerinde laboratuvar çalışmalarına gereken önemi vermeyen öğretmenlerin mezun oldukları üniversitede laboratuvar alışkanlığı kazanamadıkları, okullarında laboratuvar imkânı bulamadıkları (Demir, Böyük ve Koç, 2011), ayrıca öğretmenlerin fen laboratuvarlarında öğrencilerin performanslarını değerlendirmede etkili yöntemler konusunda deneyim eksikliği yaşadıkları (Yung, 2001) belirlenmiştir. Aynı zamanda öğretmenlerin eğitimleri sırasında uygulamalı fen eğitimine yönelik yetiştirilmemeleri, orta öğretim seviyesindeki deneyleri nasıl uygulayacakları ve laboratuvar yönetimini nasıl sağlayacakları konusunda eğitim almamaları (Nakiboğlu ve Sarıkaya, 2000) sorun oluşturmaktadır. Öğretmenlerin laboratuvar kullanma yeterlik derecesi, materyal ve ders saati yetersizliği, laboratuvar güvenliğinden kaynaklanan eksikliklerden dolayı laboratuvar uygulamalarının yeterince doğru ve etkili bir şekilde yapılamadığı anlaşılmaktadır (Böyük, Demir ve Erol 2010; Karaca, Uluçınar ve Cansaran, 2006). Başka bir çalışmanın sonucunda ise öğretmenlerin fene yönelik inanç ve düşüncelerinin de öğretim ortamında yapılacak etkinliklere yönelik kararlarında etkili olduğunu göstermektedir (Levitt, 2001). Laboratuvar uygulamalarına sorgulayıcı yaklaşımın etkisi incelendiğinde ise 
öğrencilerin soru sormada özgüven kazandığını gösteren kanıtları işaret etmektedir (Atik ve Doğan, 2020; Jeffery, Nomme, Deane, Pollock ve Birol, 2016).

Sorgulamaya dayalı laboratuvar uygulamalarıyla öğrencilerin fen bilimlerindeki akademik başarılarında belirgin artışlar sağlayabilmektedir (Aktamış, Hiğde ve Özden, 2016). Şimşek ve Karapınar (2010) çalışmalarının sonucunda, sorgulamaya dayalı öğretim ile öğrencilerin kavramsal anlama ve bilimsel süreç becerilerinin olumlu yönde etkilendiğini vurgulamaktadırlar. Çelik, Katrancı ve Çakır (2017), çalışmalarında laboratuvar ortamında gerçekleşen deneysel etkinliklerin öğrencilerin yaratıcılık becerilerini arttırmada etkili olduğu sonucunu ortaya koymuştur. Koç, Okumuş ve Öztürk (2013), laboratuvarlarda işbirlikçi bir yaklaşımla yapılan deneylerin ispat/doğrulama deneylerine göre öğrenme ürünlerinde önemli avantajlar sağladığını işaret etmektedirler. Çalışmalardan da anlaşılacağı üzere araştırmacı sorgulayıcı yaklaşım ile gerçekleşen laboratuvar ortamının önemli olduğu görülmektedir. Öğrenme ortamı olarak laboratuvar kapsamında; öğretmenlerin 21. yüzyıl eğitim dünyasında laboratuvar yeterlikleri, laboratuvara bakış açları, laboratuvar kullanımında karşılaştıkları sorunların ortaya çıarılması ve bunların daha detaylı incelenmesi laboratuvarların fen öğretimi üzerindeki etkisi için önemlidir. Ayrıca laboratuvarların önemi ve sorunlarına ilişkin çalışmalar olmakla birlikte sorgulayıcı öğrenme yaklaşımları değişen laboratuvar profilinin kontrol listesi ile doğrudan gözlenmesi fen bilgisi öğretmenlerinin değişen öğretim programı ile birlikte fen laboratuvarına ve kullanımına yönelik görüş ve tutumları ve laboratuvarı kullanabilme yeterliklerinin bir arada değerlendirilmiş olması araştırmayı fen alan yazını için değerli kılacağı literatüre faydalı olacağı ön görülmektedir.

Çalışmada, yapılan tespitler doğrultusunda fen bilgisi öğretmenlerinin sorgulayıcı yaklaşım doğrultusunda fen laboratuvarlarının uygulanabilirliğine ilişkin yeterlikleri ve karşılaştıkları sorunlar nedir? sorularına odaklanılmış ve aşağıda yer alan problemlere cevap aranmıştır:

1. Fen bilgisi öğretmenlerinin fen laboratuvarlarına yönelik yeterlikleri ne düzeydedir?

2. Cinsiyet ve mesleki kıdem bağımsız değişken olarak fen bilgisi öğretmenlerinin laboratuvar yeterliklerinde anlamlı bir farklılık oluşturmakta mıdır?

3. Fen laboratuvarlarının gözlemsel verilere ilişkin olarak fiziksel ortam, güvenlik ve öğretim programına uygunluk ölçütlerine göre mevcut durumu hangi düzeydedir?

4. Fen bilgisi öğretmenlerinin laboratuvarların fen bilimleri dersi öğretim programına uygunluğuna, kullanımına, fiziki donanımına, öğrenme ortamı olarak kullanımına, yönetmelik, yönetim ve güvenlik kaynaklı sorunlarına yönelik görüşleri nedir? 


\section{YÖNTEM}

\section{Araştırma Deseni}

Çalışmada nicel ve nitel araştırma desenlerinin birlikte ele alındığı karma yöntem deseni kullanılmıştır. Araştırmada karma araştırma yöntemi ile iki araştırma yöntemi arasında bir köprü kurulması sağlanmıştır (Onwuegbuzie ve Johnson, 2004). Çalı̧̧mada karma araştırma yöntemlerinden sıralı açımlayıcı desen tercih edilmiştir. Araştırmanın nicel araştırma deseni olarak betimsel yöntem, nitel araştırma deseni olarak ise fenomenoloji (olgu bilimi) kullanılmıştır. Fen bilgisi öğretmenlerinden anket yolu veri toplanarak geçmişte veya halen var olan bir durumu, var olduğu şekli ile laboratuvar yeteliklerinin betimlenmesi amaçlanmıştır. Fenomenolojik araştırmalar için en uygun problem türü temelde yaşanmış deneyimleri anlama ve betimlemenin önem arz ettiği bir problem olmasıdır (Tekindal ve Uğuz Arzu, 2020). Bu bakımdan öğretmen deneyimleri çalışma için önem oluşturmaktadır.

\section{Çalışma Grubu}

$\mathrm{Bu}$ çalışmada hedef evren, İç Anadolu Bölgesinde bir il merkezindeki fen bilgisi öğretmenleridir. Ancak çalışmadaki ulaşılabilir evreni ise il merkezinde ortaokullarda çalışan 113 fen bilgisi öğretmeninden çalışmaya gönüllü katılan 79 fen bilgisi öğretmenidir. Araştırma grubunun belirlenmesinde kolay ulaşılabilir örnekleme yöntemi tercih edilmiştir. Kolay ulaşılabilir örneklem araştırmaya hız ve pratiklik kazandırmaktadır (Merriam, 2013). Laboratuvar yeterlik ölçeği ve çalışmaya gönüllü katılan 20 öğretmenden ise nitel görüşme formu ile veri elde edilmiştir. "Fen Bilimleri Laboratuvar Kontrol Listesi", 32 merkez devlet ortaokulundan 27 okul laboratuvarlarında uygulanmıştır. Öğretmenlerin bir kısmının idareci olması, kontrol listesi uygulanırken 2 adet okulun fiziki olarak geçici başka bir okul bünyesinde eğitim vermesi, 3 adet okulda ise laboratuvar ortamının hiç olmaması sebebiyle çalışma dışında bırakılmıştır.

Çalışmaya katılan öğretmenlerin demografik özellikleri incelendiğinde; öğretmenlerin \%48,1'i kadın iken \%51,9’u erkektir. Öğretmenlerin \%3,8`i 1 yıldan az süredir, \%10,1'i 1-5 yıldır, \%20,3’ü 6-10 yıldır, \%10,15‘i 10-15 yıldır, \%36,7’si 15 yıldan fazla süredir çalışmaktadır.

\section{Veri Toplama Araçları}

Araştırmada nicel verilerin toplanması için "Fen Bilimleri Öğretmenlerinin Laboratuvar Çalışmalarına Yönelik Yeterlik Ölçeği” kullanılmıştır. Kaya ve ark. (2004), tarafından geliştirilen ölçek 18 maddeden oluşmaktadır ve 5'li Likert tipindedir. Böyük ve ark. (2010) tarafından uygulanan ölçeğe ilişkin alfa iç tutarlılık katsayısı 0.92 olarak tespit edilmiştir. Aynı zamanda "Fen Bilimleri Laboratuvar Kontrol Listesi" fen bilgisi eğitiminde uzman iki akademisyen ve 3 fen bilgisi öğretmeninin görüşleri doğrultusunda geliştirilmiştir. Bu yöntemle veri toplama 
aracının kapsam geçerliliği sağlanmıştır. Nitel verilerin toplanmasında ise yarı yapılandırılmış görüşme formu kullanılmıştır. Sorular araştırmacı tarafından ve iki akademisyen, üç fen bilimleri öğretmeni görüşü alınarak hazırlanmıştır. Son hali 10 sorudan oluşmuş ve görüşme süresi her bir katılımcıyla yaklaşık 30 dakika sürmüştür. Wolcott (2009), bir bilimsel çalışmada katılımcıların sözlerinden doğrudan alıntı yapılmasının araştırmanın geçerliliği açısından önem arz ettiğini belirtmiştir. Bu nedenle mülakatlar aracılığıyla toplanan verilerin bir kısmı bulgular bölümünde doğrudan alıntı yapılarak sunulmuştur. Bu sayede inandırıcılık arttırılmaya çalışılmıştır.

\section{Verilerin Analizi}

Araştırma kapsamında, fen bilgisi öğretmenlerinin fen laboratuvarlarına yönelik yeterliklerini değerlendirmek için elde edilen verilerin analizi istatistik paket programı ile yapılmış ve \%95 güven düzeyi ile çalışılmıştır. Yapılan Kolmogorov-smirnov testi sonuçlarına göre; laboratuvar çalışmalarına yönelik yeterlik puanı normal dağılım gösterdiğinden ( $p=0.178$; p>0,05) karşılaştırma analizlerinde parametrik yöntemler kullanılmıştır. Çalışmada test tekniklerinden bağımsız gruplar t testi, ANOVA testi kullanılmıştır. Çalışmada ölçek puanlarının demografik değişkenlere göre farklılık göstermesi ise bağımsız gruplar $\mathrm{t}$ testi, ANOVA testi ile analiz edilmiştir.

Çalışmanın hedefleri doğrultusunda fen bilgisi öğretmenlerinin laboratuvarların fen bilimleri dersi öğretim programına uygunluğuna, kullanımına, fiziki donanımına, öğrenme ortamı olarak kullanımına, yönetmelik, yönetim ve güvenlik kaynaklı sorunlarına yönelik görüşleri belirlemek için elde edilen nitel veriler görüşme formu vasıtasıyla alınmış, analizi ise içerik analiz şeklinde yapılmıştır. Veriler arasında yer alan anlamlı bölümlere (sözcük, cümle vb.) ortak isimler verilerek kodlanmıştır. İçerik analizinde verilerin kavramsallaştırılması ve olguyu tanımlayabilecek temaların ortaya çıkarılması çabası vardır. İçerik analizinin son aşamasında kategorilere bir isim verilmeye çalışılır. Kategorilerin isimleri; araştırmacı, katılımcı veya alan yazın kaynaklı olabilir (Merriam, 2013). İçerik analizinde sonuçlar betimsel bir anlatım ile sunulur ve sık sık doğrudan alıntılara yer verilir (Yıldırım ve Şimşek, 2016).

\section{BULGULAR}

Bu bölümde araştırma problemlerine yanıt oluşturmak için nitel ve nicel verilerden elde edilen bulgular verilerek ayrı ayrı yorumlanmıştır.

\section{Nicel Veri Uygulamalarına Ait Bulgular}

Bu bölümde öğretmenlere uygulanan yeterlik ölçeği neticesinde elde edilen verilerin sonuçları yer almaktadır. Öğretmenlerin laboratuvar çalışmalarına yönelik yeterlilik düzeyleri Tablo 1'de verilmiştir. 
Tablo 1.

Öğretmenlerin Laboratuvar Çalışmalarına Yönelik Yeterlik Bilgilerinin Dağılımı

\begin{tabular}{|c|c|c|c|c|c|c|c|}
\hline & Madde & 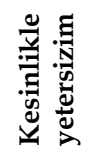 & 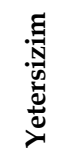 & 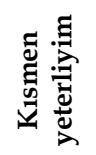 & 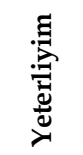 & 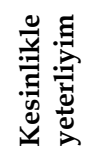 & $\overline{\mathbf{X}}$ \\
\hline 1 & Laboratuvar yönteminin fen öğretimindeki önemini bilme & 0,0 & 0,0 & 10,1 & 44,3 & 45,6 & 4,4 \\
\hline 2 & $\begin{array}{l}\text { Laboratuvar yöntemini uygulamada kullanılan öğretim } \\
\text { yöntem ve tekniklerini bilme }\end{array}$ & 0,0 & 0,0 & 12,7 & 60,8 & 26,6 & 4,1 \\
\hline 3 & $\begin{array}{l}\text { Laboratuvar yöntemini uygulamada kullanılan, öğretim } \\
\text { yöntem ve tekniklerini derslerde kullanabilme }\end{array}$ & 0,0 & 0,0 & 13,9 & 59,5 & 26,6 & 4,1 \\
\hline 4 & $\begin{array}{l}\text { Laboratuvarda güvenli bir çalışma ortamı oluşturmak için } \\
\text { gerekli tüm bilgi ve becerilere sahip olma }\end{array}$ & 0,0 & 1,3 & 17,7 & 49,4 & 31,6 & 4,1 \\
\hline 5 & $\begin{array}{l}\text { Fen laboratuvarındaki tüm araç gereçleri tanıma ve } \\
\text { kullanabilme }\end{array}$ & 0,0 & 0,0 & 21,5 & 53,2 & 25,3 & 4,0 \\
\hline 6 & $\begin{array}{l}\text { Laboratuvardaki araç gereçlerle ilgili basit bakım onarım } \\
\text { bilgi ve becerisine sahip olma }\end{array}$ & 0,0 & 3,8 & 32,9 & 50,6 & 12,7 & 3,7 \\
\hline 7 & Laboratuvarda etkili bir öğretim ortamı düzenleyebilme & 0,0 & 0,0 & 11,4 & 54,4 & 34,2 & 4,2 \\
\hline 8 & $\begin{array}{l}\text { Laboratuvar yöntemini derslerde kullanmaya karşı istekli } \\
\text { olma }\end{array}$ & 0,0 & 1,3 & 17,7 & 39,2 & 41,8 & 4,2 \\
\hline 9 & $\begin{array}{l}\text { Fen ve Teknoloji öğretimi için geliştirilen yeni araç gereçleri } \\
\text { merak etme ve derslerde kullanmaya istekli olma }\end{array}$ & 0,0 & 2,5 & 12,7 & 55,7 & 29,1 & 4,1 \\
\hline 10 & $\begin{array}{l}\text { Laboratuvar uygulamaları için basit araç gereçler geliştirme } \\
\text { ve kullanma becerisine sahip olma }\end{array}$ & 1,3 & 1,3 & 20,3 & 51,9 & 25,3 & 4,0 \\
\hline 11 & $\begin{array}{l}\text { Öğrencilerin laboratuvar çalışmaları ile ilgili bilgi ve } \\
\text { becerileri ölçme bilgisine sahip olma }\end{array}$ & 0,0 & 1,3 & 10,1 & 63,3 & 25,3 & 4,1 \\
\hline 12 & $\begin{array}{l}\text { Öğrencilerin laboratuvar çalışmalarıyla ilgili tutumlarını } \\
\text { ölçme bilgisine sahip olma }\end{array}$ & 0,0 & 1,3 & 19,0 & 58,2 & 21,5 & 4,0 \\
\hline 13 & Verilen bir deney için uygun araç gereçleri seçme & 0,0 & 0,0 & 6,3 & 45,6 & 48,1 & 4,4 \\
\hline 14 & Çabuk ve doğru araç gereçlerle d & 0,0 & 0,0 & 13,9 & 49,4 & 36,7 & 4,2 \\
\hline 15 & k kurallarını takip etme & 0,0 & 0,0 & 6,3 & 53,2 & 40,5 & 4,3 \\
\hline 16 & $\begin{array}{l}\text { Deney sonrası, ekipmanları yerlerine temiz ve düzenli olarak } \\
\text { koyma }\end{array}$ & 0,0 & 1,3 & 3,8 & 44,3 & 50,6 & 4,4 \\
\hline 17 & Deney sonuçlarını yorumlama & 0,0 & 0,0 & 3,8 & 39,2 & 57,0 & 4,5 \\
\hline 18 & $\begin{array}{l}\text { Deney sonuçlarını teorik bilgilerle bütünleştirerek yeni } \\
\text { sonuçlar üretme }\end{array}$ & 0,0 & 0,0 & 8,9 & 57,0 & 34,2 & 4,3 \\
\hline
\end{tabular}

Öğretmenlerin en yüksek katılım gösterdikleri yeterlik deney sonuçlarını yorumlama iken $(\bar{X}=4,5)$ en düşük katılım gösterdikleri yeterlik laboratuvar malzemelerine ilişkin bakım ve onarım bilgi ve becerisine sahip olma $(\bar{X}=3,7)$ şeklinde görülmektedir. Tablo 1, fen bilgisi öğretmenlerinin laboratuvar yeterlikleri konusunda fen öğretimi için olumlu sonuçlar yansıtmaktadır. Tablo 2'de öğretmenlerin laboratuvar çalışmalarına yönelik yeterlik puanının genel görünümü yer almaktadır.

Tablo 2.

Öğretmenlerin Laboratuvar Çalışmalarına Yönelik Yeterlik Puanının Betimleyici İstatistikleri

\begin{tabular}{ccccc}
\hline Min. & Mak. & $\overline{\mathbf{X}}$ & SS & Düzey (\%) \\
\hline 58 & 90 & 4,19 & 0,43 & 83,76 \\
\hline
\end{tabular}

Fen bilgisi öğretmenlerinin laboratuvar çalışmalarına yönelik 18 maddenin toplamından elde edilen yeterlik puan ortalaması 75,38 olarak hesaplanmıştır. Genel düzey incelendiğinde 
$(\bar{X}==4,19)$ fen bilgisi öğretmenlerin kendilerini yeterli algıladıkları görülmektedir (Aralık Sayısı/Seçenek sayısı). Bağımsız değişkenlerin etkilerini incelemek üzere gerekli anlamlılık testlerini belirlemeye yönelik yapılan Kolmogorov-smirnov testi sonuçlarına göre; laboratuvar çalışmalarına yönelik yeterlik puanı $(p=0,178)$ normal dağılım gösterdiğinden $(p>0,05)$ karşılaştırma analizlerinde parametrik yöntemler kapsamında t-testi kullanılmıştır ve Tablo 3 'te sunulmuştur.

Tablo 3.

Öğretmenlerin Cinsiyetlerinin Laboratuvar Çalışmalarına Yönelik Yeterlik Puanı Bakımından Karşılaştırılması

\begin{tabular}{lcccccc}
\hline Cinsiyet & $\mathbf{N}$ & $\overline{\mathbf{X}}$ & sd & SS & t & $\mathbf{p}$ \\
\hline Kadin & 38 & 4,29 & 77 & 0,43 & 2,000 & $0,049^{*}$ \\
Erkek & 41 & 4,06 & & 0,42 & & \\
\hline${ }^{*} p<0,05$ & & & & & &
\end{tabular}

Yapılan bağımsız gruplar t testi sonuçlarına göre; kadın öğretmenlerin lehine laboratuvar çalışmalarına yönelik yeterlik puanı bakımından istatistiksel anlamlı fark bulunmaktadır $(\overline{\mathrm{X}}=4,29 ; \mathrm{p}=0.049)$. Çalışma grubunun görev yılına göre analizi ise Tablo 4'te verilmiştir.

Tablo 4.

Öğretmenlerin Hizmet Süresinin Laboratuvar Çalışmalarına Yönelik Yeterlik Puanı Bakımından Karşılaştırılması

\begin{tabular}{lcccccc}
\hline Hizmet süresi & $\mathbf{N}$ & $\overline{\mathbf{X}}$ & sd & SS & $\mathbf{F}$ & $\mathbf{p}$ \\
\hline 5 yll ve daha az & 11 & 4,27 & $3-78$ & 0,53 & 2,440 & 0,071 \\
6-10 y1l & 16 & 4,18 & & 0,41 & & \\
10-15 yll & 23 & 4,00 & & 0,42 & & \\
15 ylldan fazla & 29 & 4,21 & & 0,38 & & \\
${ }^{{ }^{p}<00,05}$ & & & & &
\end{tabular}

Tabloda hizmet süresi farklı öğretmenler için laboratuvar çalışmalarına yönelik yeterlik puanı bakımından karşılaştırma analizi sonuçları görülmektedir. Yapılan ANOVA testi sonuçlarına göre; hizmet süresi farklı olanlar arasında laboratuvar çalışmalarına yönelik yeterlik puanı bakımından istatistiksel anlamlı fark bulunmamaktadır.

Araştırmanın üçüncü alt problemi için 27 okulun fen laboratuvarının kontrol listesi doğrultusundaki gözlem yolu ile elde edilen veri analizleri yer almaktadır. Geliştirilen form aracılığı ile fen bilimleri laboratuvarların fiziksel ve güvenlik standartlarına uygun olup olmadığı belirlenmiş, Tablo 5 ve Tablo 6 'da sunulmuş, ayrıca öğretim programına ilişkim gözlemsel analizler ise Tablo 7' de verilmiştir. 
Tablo 5.

Laboratuvar Fiziksel Ortamı Kontrol Listesi

\begin{tabular}{|c|c|c|c|c|c|c|}
\hline \multirow{2}{*}{ Maddeler } & \multicolumn{2}{|c|}{ Evet } & \multicolumn{2}{|c|}{ Hayir } & \multicolumn{2}{|c|}{ Kismen } \\
\hline & $\mathbf{N}$ & $\%$ & $\mathbf{N}$ & $\%$ & $\mathbf{N}$ & $\%$ \\
\hline Laboratuvarın fiziki konumu (okul içindeki) kullanıma uygundur. & 17 & 62,96 & 6 & 22,22 & 4 & 14,81 \\
\hline $\begin{array}{l}\text { Laboratuvarın kullanım alanı ortalama öğrenci sayısına göre } \\
\text { planlanmıştır. }\end{array}$ & 16 & 59,26 & 6 & 22,22 & 5 & 18,52 \\
\hline Laboratuvarın aydınlatılması yeterli düzeydedir. & 17 & 62,96 & 3 & 11,11 & 7 & 25,93 \\
\hline Laboratuvarın aydınlatılması gerektiğinde ayarlamaya elverişlidir. & 8 & 29,63 & 13 & 48,15 & 6 & 22,22 \\
\hline $\begin{array}{l}\text { Laboratuvarda kullanılan sıhhi tesisat her bir çalışma masasına } \\
\text { hizmet edecek şekilde planlanmıştır. }\end{array}$ & 10 & 37,04 & 11 & 40,74 & 6 & 22,22 \\
\hline $\begin{array}{l}\text { Laboratuvar malzemelerinin yerleştirileceği dolap yeterli } \\
\text { düzeydedir. }\end{array}$ & 17 & 62,96 & 3 & 11,11 & 7 & 25,93 \\
\hline $\begin{array}{l}\text { Laboratuvar malzemeleri planlı ve düzenli bir şekilde dolaplara } \\
\text { yerleştirilmiştir }\end{array}$ & 15 & 55,56 & 1 & 3,70 & 11 & 40,74 \\
\hline $\begin{array}{l}\text { Laboratuvar ortamina ek oda olarak malzeme deposuna yer } \\
\text { verilmiştir. }\end{array}$ & 11 & 40,74 & 11 & 40,74 & 5 & 18,52 \\
\hline $\begin{array}{l}\text { Laboratuvar kullanımı amacı dışında, kuruma hizmet } \\
\text { sağlamamaktadır. }\end{array}$ & 14 & 51,85 & 9 & 33,33 & 4 & 14,81 \\
\hline $\begin{array}{l}\text { Laboratuvardaki masa, sandalyelerin kullanımı öğrenci fiziksel } \\
\text { yapısına uygundur. }\end{array}$ & 14 & 51,85 & 4 & 14,81 & 9 & 33,33 \\
\hline Laboratuvar zemini temizlik ve hijyeni kolaylaştırır niteliktedir. & 16 & 59,26 & 3 & 11,11 & 8 & 29,63 \\
\hline
\end{tabular}

Gözlemsel kontrol sonuçlarına göre; laboratuvarın fiziksel ortamı, laboratuvarın fiziki konumu (okul içindeki), aydınlatma düzeyi, malzeme dolabı yeterlik düzeyi ve kullanım alanının ortalama öğrenci sayısına göre uygunluk düzeyi olumlu gözlemlenmiştir. Buna karşıt olarak aydınlatma düzeyinin ayarlanabilir olması, tesisatların her bir masaya uzanımı, ek birer malzeme deposuna yer verilme durumu konularında olumsuz gözlemler söz konusu olmuştur.

Tablo 6.

Laboratuvar Güvenliği Kontrol Listesi

\begin{tabular}{|c|c|c|c|c|c|c|}
\hline \multirow{2}{*}{ Maddeler } & \multicolumn{2}{|c|}{ Evet } & \multicolumn{2}{|c|}{ Hayir } & \multicolumn{2}{|c|}{ Kismen } \\
\hline & $\mathbf{N}$ & $\%$ & $\mathbf{N}$ & $\%$ & $\mathbf{N}$ & $\%$ \\
\hline Laboratuvarda tehlike ve uyarı sembolleri vardır. & 8 & 29,63 & 12 & 44,44 & 7 & 25,93 \\
\hline Laboratuvar kullanma talimatı görülebilir bir yerdedir. & 7 & 25,93 & 16 & 59,26 & 4 & 14,81 \\
\hline Kimyasallar uygun koşullarda saklanmıştır. & 17 & 62,96 & 4 & 14,81 & 6 & 22,22 \\
\hline $\begin{array}{l}\text { Laboratuvarlar gerektiğinde kullanılmak üzere el, göz ve yüz } \\
\text { koruyucuları mevcuttur. }\end{array}$ & 14 & 51,85 & 4 & 14,81 & 9 & 33,33 \\
\hline Laboratuvarın konumu havalandırmaya uygundur. & 20 & 74,07 & 2 & 7,41 & 5 & 18,52 \\
\hline Laboratuvarda yangın söndürücü vardır. & 3 & 11,11 & 24 & 88,89 & 0 & 0,00 \\
\hline
\end{tabular}


Tablo 6 (Devam)

\begin{tabular}{lcccccc}
\hline Laboratuvarda ilk yardım seti vardır. & 5 & 18,52 & 21 & 77,78 & 1 & 3,70 \\
Laboratuvarda elektrik tesisatı için tedbir alınmıştır. & 16 & 59,26 & 4 & 14,81 & 7 & 25,93 \\
Laboratuvar kapısında görüş paneli vardır. & 6 & 22,22 & 21 & 77,78 & 0 & 0,00 \\
Laboratuvar ortamı deprem yönetmeliğine uygundur. & 7 & 25,93 & 13 & 48,15 & 7 & 25,93 \\
\hline
\end{tabular}

Laboratuvarın güvenliği ile ilgili en fazla evet yanıtı verilen ifadeler sırasıyla; "Laboratuvarın konumu havalandırmaya uygundur", "Kimyasallar uygun koşullarda saklanmıştır ve "Laboratuvarda elektrik tesisatı için tedbir alınmıştır" ifadeleridir. Olumsuz gözlemlenen durumlar ise, kısa mesafede yangın söndürücü olmaması, ilkyardım seti olmaması, laboratuvar kapı görüş paneli ve kullanım talimatların görsel ve görülebilir konumu hususlarıdır.

Tablo 7.

Laboratuvarın Programa Uygunluğunun Kontrol Listesi

\begin{tabular}{|c|c|c|c|c|c|c|}
\hline \multirow{2}{*}{ Maddeler } & \multicolumn{2}{|c|}{ Evet } & \multicolumn{2}{|c|}{ Hayır } & \multicolumn{2}{|c|}{ Kismen } \\
\hline & $\mathbf{N}$ & $\%$ & $\mathbf{N}$ & $\%$ & $\mathbf{N}$ & $\%$ \\
\hline $\begin{array}{l}\text { Laboratuvar malzemelerinin niteliği, program kazanımlarını } \\
\text { destekleyecek sonuçlar üretebilir düzeydedir. }\end{array}$ & 15 & 55,56 & 1 & 3,70 & 11 & 40,74 \\
\hline $\begin{array}{l}\text { Laboratuvar çalışma ortamı, güncel öğretim programındaki } \\
\text { yöntem-teknik ve modellere göre planlanmaya elverişlidir. }\end{array}$ & 15 & 55,56 & 2 & 7,41 & 10 & 37,04 \\
\hline $\begin{array}{l}\text { Laboratuvar ortamı öğrencilerin duyuşsal gelişimini } \\
\text { destekleyecek şekilde tasarlanmıştır. }\end{array}$ & 10 & 37,04 & 4 & 14,81 & 13 & 48,15 \\
\hline $\begin{array}{l}\text { Laboratuvar ortamında yapılan tasarımlar, programdaki FTTÇ } \\
\text { kazanımları ile örtüşmektedir. }\end{array}$ & 15 & 55,56 & 3 & 11,11 & 9 & 33,33 \\
\hline $\begin{array}{l}\text { Laboratuvarda gerektiğinde kullanılmak üzere gündelik } \\
\text { anlamda basit araç-gereçlere yer verilmektedir. }\end{array}$ & 22 & 81,48 & 1 & 3,70 & 4 & 14,81 \\
\hline $\begin{array}{l}\text { Öğretim programında yer alan bilişsel öğrenme alanlarına ilişkin } \\
\text { deneyleri yapabilecek yeterlilikte deney malzemeleri vardır. }\end{array}$ & 17 & 62,96 & 2 & 7,41 & 8 & 29,63 \\
\hline
\end{tabular}

Laboratuvarların programa uygunluğu ile ilgili en fazla evet yanıtı verilen ifadeler sırasıyla; "Laboratuvarda gerektiğinde kullanılmak üzere gündelik anlamda basit araç-gereçlere yer verilmektedir" ve "Öğretim programında yer alan bilişsel öğrenme alanlarına ilişkin deneyleri yapabilecek yeterlilikte deney malzemeleri vardır" ifadeleridir. Programa uygunluğu konusunda algılar kararsızlığı ya da kısmi yeterliliği işaret eden yoğunluğa sahip olduğu dikkat çekmektedir.

\section{Nitel Veri Uygulamalarına Ait Bulgular}

$\mathrm{Bu}$ bölümde yarı yapılandırılmış görüşme sorularından elde edilen bulgulara yer verilmiştir. Fen bilgisi öğretmenlerinin okulda laboratuvar bulunma durumuna yönelik cevapları Tablo 8 'de yer almaktadır. 
Tablo 8.

Okulda Laboratuvar Bulunma Durumu

\begin{tabular}{lll}
\hline Kodlar & f & Katılımcı \\
\hline Laboratuvar var & 17 & $\mathrm{~K} 1, \mathrm{~K} 2, \mathrm{~K} 3, \mathrm{~K} 4, \mathrm{~K} 5, \mathrm{~K} 6, \mathrm{~K} 7, \mathrm{~K} 8, \mathrm{~K} 9, \mathrm{~K} 10, \mathrm{~K} 11, \mathrm{~K} 12, \mathrm{~K} 15, \mathrm{~K} 17, \mathrm{~K} 18, \mathrm{~K} 19, \mathrm{~K} 20$ \\
Aktif değil & 3 & $\mathrm{~K} 13, \mathrm{~K} 14, \mathrm{~K} 16$ \\
\hline
\end{tabular}

Elde edilen veriler göre 17 okulda laboratuvar olduğu, üç okulda ise laboratuvarların aktif olmadığı sonucuna ulaşılmıştır. Araştırma grubunun okulda fen laboratuvarını kullanma durumuna yönelik belirtmiş oldukları cevaplar ise Tablo 9' da sunulmuştur.

Tablo 9.

Laboratuvar Kullanma Durumu

\begin{tabular}{|c|c|c|c|}
\hline Temalar & Kodlar & f & Katılımc1 \\
\hline \multirow[t]{2}{*}{$\begin{array}{l}\text { Kullanma } \\
\text { Durumu }\end{array}$} & Kullaniyorum & 14 & $\begin{array}{l}\text { K1, K4, K3, K5, K6, K7, K8, } \\
\text { K11, K13, K14, K15, K16, } \\
\text { K19, K20 }\end{array}$ \\
\hline & Bazen kullaniyorum & 4 & K9, K12, K17, K18 \\
\hline \multirow[b]{2}{*}{ Olumlu } & $\begin{array}{l}\text { Laboratuvar kullandığımızda öğrenciler daha istekli } \\
\text { ve meraklı oluyor }\end{array}$ & 1 & K1 \\
\hline & $\begin{array}{l}\text { Laboratuvar kullandığımızda öğrenciler konuları } \\
\text { daha kolay kavrıyor }\end{array}$ & 3 & $\mathrm{~K} 1, \mathrm{~K} 14, \mathrm{~K} 20$ \\
\hline \multirow{5}{*}{ Olumsuz } & $\begin{array}{l}\text { Laboratuvar malzemelerini sınıfa taşınarak } \\
\text { kullanıyoruz }\end{array}$ & 2 & $\mathrm{~K} 2, \mathrm{~K} 3$ \\
\hline & $\begin{array}{l}\text { Laboratuvara git gel zaman kaybı olduğundan tercih } \\
\text { etmiyorum }\end{array}$ & 2 & $\mathrm{~K} 2, \mathrm{~K} 4$ \\
\hline & Ders uygun olduğunda tercih ediyorum & 2 & K9, K10 \\
\hline & Laboratuvar yetersiz & 3 & $\mathrm{~K} 11, \mathrm{~K} 12, \mathrm{~K} 13$ \\
\hline & Laboratuvarda öğrencileri kontrol etmek zor & 2 & $\mathrm{~K} 17, \mathrm{~K} 18$ \\
\hline
\end{tabular}

Tablo 9'da okullarda laboratuvar kullanmanın avantajları ve dezavantajları ayrı temalar altında incelenmiştir. Elde edilen veriler göre 14 öğretmen laboratuvarı aktif olarak kullandığını belirtirken, dört öğretmen bazen kullandığını ifade etmiştir. Üç katılımcı laboratuvar kullandıklarında öğrencilerin konuları daha kolay kavradıklarını belirtirken, farklı üç katılımcı ise laboratuvarlarının yetersiz olduğundan bahsetmiştir. Bu bağlamda K1 laboratuvar kullanımına ilişkin; "Kullanıyorum. Öğrenciler daha istekli ve meraklı oluyorlar. Öğrenme daha kolay gerçekleşiyor" şeklinde cevap vermiştir. K12 ise bazen laboratuvar kullanma durumu nedenini şu şekilde aktarmaktadır: "Bazen kullanıyorum. Çünkü laboratuvardaki malzeme eksikliği deneyleri yapmama engel oluyor". K11 laboratuvarlarının yetersiz oluşunu "2017-2018 eğitim öğretim yılında 
Laboratuvar ortamı kullanamıyoruz. Okulumuz taşındığı için bina yetersiz. Laboratuvar çok küçük bir sınıfa kurulduğu için kullanıma uygun değil!" şeklindeki görüşü ile aktarmıştır.

Çalışma gurubundaki katılımcılara "Laboratuvarı kullanımı açısından kendinizi yeterli hissediyor musunuz? Nedenleriyle açıklayınız" temel sorusu yöneltilmiştir. Katılımcılardan gelen dönütler Tablo $10^{\prime}$ da verilmiştir.

Tablo 10.

Laboratuvar Kullanım Yeterliliği

\begin{tabular}{|c|c|c|c|}
\hline Temalar & Kodlar & $\mathbf{f}$ & Katılımcı \\
\hline \multirow{7}{*}{ Yeterli } & $\begin{array}{l}\text { Yeterli hissediyorum } \\
\text { Laboratuvar öğrenmenin kalıcı olabilmesi } \\
\text { açısından etkili öğrenme sağlamaktadır }\end{array}$ & $\begin{array}{c}16 \\
5\end{array}$ & $\begin{array}{l}\text { K1, K2, K4, K5, K6, K7, K8, K9, } \\
\text { K10, K11, K12, K14, K15, K16, } \\
\text { K17, K18 } \\
\text { K7, K10, K11, K14, K15 }\end{array}$ \\
\hline & Kısmen yeterli hissediyorum & 2 & K3, K13 \\
\hline & $\begin{array}{l}\text { Üniversite eğitiminde yeterli eğitimi } \\
\text { aldım }\end{array}$ & 2 & $\mathrm{~K} 2, \mathrm{~K} 12$ \\
\hline & $\begin{array}{l}\text { Müfredatta geçen deneyler öğrencilerin } \\
\text { yapabileceği } \quad \text { ve anlayabileceği }\end{array}$ & 2 & K8, K89 \\
\hline & düzeydedir & & \\
\hline & $\begin{array}{l}\text { Laboratuvar dışı basit deneylerde } \\
\text { yapıyoruz }\end{array}$ & 2 & $\mathrm{~K} 15, \mathrm{~K} 16$ \\
\hline & Mesleki tecrübemden ötürü yeterliyim & 2 & K5, K11 \\
\hline \multirow{6}{*}{ Yetersiz } & Bazen yeterli olamayabiliyorum & 2 & K7, K18 \\
\hline & $\begin{array}{l}\text { Malzeme eksikliğinde üretken } \\
\text { olamiyorum }\end{array}$ & 1 & K3 \\
\hline & $\begin{array}{l}\text { Kimyasal madde kullanıminda } \% 100 \\
\text { yeterli hissetmiyorum }\end{array}$ & 1 & K2 \\
\hline & $\begin{array}{l}\text { Tecrübeli öğretmenlerden bazen destek } \\
\text { alıyorum }\end{array}$ & 1 & K17 \\
\hline & $\begin{array}{l}\text { Teknik eğitim almadığım için yeterli } \\
\text { değilim }\end{array}$ & 1 & K19 \\
\hline & $\begin{array}{l}\text { Tecrübesizlikten } \quad \text { dolayı } \quad \text { yetersiz } \\
\text { hissediyorum }\end{array}$ & 1 & K20 \\
\hline
\end{tabular}


Tablo 10'da incelendiğinde 16 katılımcı laboratuvar kullanımı konusunda kendilerini yeterli gördüklerini belirtmiştir. Beş katılımcı laboratuvarın, öğrenmenin kalıcı olabilmesi açısından etkili öğrenme sağladığını savunmuştur. İki katılımcı ise bazen yeterli olmadıklarını dile getirmişlerdir. Elde edilen verilerin 1şığında K7 laboratuvar kullanım yeterliliğine ilişkin; "Evet yeterli hissediyorum. Laboratuvarda deneyler yapılınca öğrenme daha güzel ve kahıcı oluyor. Bazen bazı konularda yerli olamadığımda olabiliyor" şeklinde görüşlerini sunmuştur. K15 laboratuvar kullanımına ilişkin kendini yeterli hissetmesini ve laboratuvarın etkili öğrenmede önemli olduğunu şu cümleleri ile açıklamıştır: "Evet yeterli hissediyorum. Teorik anlamda yeterli olan bilgiye sahibim. Ancak çocukların dersi daha iyi ve kalıcllk açısından basit bir deneyle bile bilgileri daha anlaşılır hale getirebiliyorum. Sadece laboratuvarda değil bazen günlük hayattan getirebildiğimiz basit malzemelerle de deney yapabiliyor programı uygulayabiliyoruz".

Laboratuvardaki malzemelerin mevcut öğretim programına uygunluğunu sağlamayabilme durumu Tablo 11'de incelenmiştir.

Tablo 11.

Mevcut Öğretim Programının Uygulanabilirliği Bakımından Laboratuvardaki Malzemelerin Özelliğinin Amaca Hizmet Etmesi Durumu

\begin{tabular}{|c|c|c|}
\hline Kodlar & $\mathbf{f}$ & Katılımcı \\
\hline Amaca hizmet etmekte & 6 & $\begin{array}{l}\text { K1, K6, K8, K10, K11, } \\
\text { K15 }\end{array}$ \\
\hline Amaca hizmet etmiyor & 6 & $\begin{array}{l}\text { K7, K12, K13, K16, K17, } \\
\text { K19 }\end{array}$ \\
\hline Eksik ve gereksiz malzemeler var & 6 & $\begin{array}{l}\mathrm{K} 5, \mathrm{~K} 7, \mathrm{~K} 9, \mathrm{~K} 11, \mathrm{~K} 12, \\
\mathrm{~K} 13\end{array}$ \\
\hline Kismen hizmet etmekte & 5 & K3, K5, K14, K18, K20 \\
\hline $\begin{array}{l}\text { Laboratuvar malzemeleri öğretim programına göre } \\
\text { güncellenmelidir }\end{array}$ & 4 & $\mathrm{~K} 2, \mathrm{~K} 4, \mathrm{~K} 5, \mathrm{~K} 17$ \\
\hline $\begin{array}{l}\text { Müfredatın sürekli değişmesi uygun malzeme konusunda } \\
\text { sorun çıkartıyor }\end{array}$ & 4 & K9, K12, K17, K19 \\
\hline Müfredat ile paralel laboratuvar malzemeleri yenilenmelidir & 3 & $\mathrm{~K} 3, \mathrm{~K} 13, \mathrm{~K} 16$ \\
\hline Daha az ve malzeme ile basit ve anlaşılır deneyler yapılıyor & 1 & K15 \\
\hline $\begin{array}{l}\text { Mühendislik uygulamalarına yönelik farklı malzemeler } \\
\text { gerekecektir }\end{array}$ & 1 & K2 \\
\hline
\end{tabular}

Katılımcıların cevaplarından elde edilen veriler göre 6 katılımcı laboratuvarların amaca uygun hizmet ettiğini belirtirken, 5 katılımcı kısmen hizmet ettiğini, 6 katılımcı ise amaca hizmet etmediğini belirtmiştir. 6 katılımcı ise eksik ve gereksiz malzemelerin olduğunu dile getirmiştir. 
Elde edilen verilerden yola çıkarak, K10 laboratuvar malzemelerinin yeterliliğini "Evet etmektedir. Malzemeler mevcut öğretim programını uygulanmasında yeterli ve uyumludur" şeklinde dile getirmiştir. K5 ise soru ile ilgili görüşlerini "Kısmen. Bazı malzemeler laboratuvarda fazlalık, bazıları da eksik" diyerek belirtmiştir.

Çalışma gurubundaki katılımcılara "Fen laboratuvarındaki malzemeler yeterli sayıda mı?" sorusu yöneltilmiştir. Katılımcılardan alınan kavramlar Tablo 12' de yer almaktadır.

Tablo 12.

Laboratuvar Malzemelerin Yeterlilikleri

\begin{tabular}{lll}
\hline Kodlar & f & Kat1lımc1 \\
\hline Yeterli & 10 & K4, K5, K6, K8, K9, K10, K11, K14, K15, K16 \\
Kismen yeterli & 5 & K1, K7, K17, K18, K20 \\
Yeterli değil & 5 & K2, K3, K12 K13, K19 \\
\hline
\end{tabular}

Analiz neticesinde genel görüşün olumlu olduğu yani yeterli (10 katılımcı) olduğu anlaşılmaktadır. Malzemelerin yeterli olduğu görüşünde olan K4 "Mevcut programda laboratuvar malzemelerini yeterli buluyorum. Gruplar halinde yapilan deneylerde malzeme sayllan artırlmalı." şeklinde laboratuvarlarının durumunu aktarmıştır. K20 ise görüşlerini şu şekilde aktarmıştır: "Bazı deneylerde yeterli ve hatta fazlalık varken bazı deney malzemelerinde eksiklik var. Bunu önlemek için il merkezinde laboratuvar merkezi olmal ve merkezlerde fazlahklar toparlanip eksik olan okullarda buralardan eksiklerini tamamlamalı. Bireysel çalışmalar için yetersiz bundan dolayı gösterip yaptırma ya da grup çalışmaları yapıyoruz".

Fen bilgisi öğretmenlerinin laboratuvar kullanımı sırasında sınıf yönetimi açısından yaşamış oldukları sorunlar Tablo 13'te sunulmaktadır.

Tablo 13.

Laboratuvarda Sınıf Yönetimi

\begin{tabular}{lll}
\hline Kodlar & f & \multicolumn{1}{c}{ Katılımc1 } \\
\hline Öğrenciler deney ve laboratuvar kültürüne sahip & 10 & $\begin{array}{l}\text { K1, K2, K3, K5, K7, K9, K11, K13, K16, } \\
\text { değil }\end{array}$ \\
Sinıf mevcudundan ötürü sınıf kontrolü zor & 9 & K1, K7, K8, K11, K12, K13, K14, K17, K19 \\
Rehberliğe dayalı deney yapılıyor & 7 & K2, K3, K6, K7, K8, K14, K16 \\
Öğrencilere zarar verebilecek araçlar yer almaktadır & 3 & K4, K15, K19 \\
Laboratuvar ortamında deney yaparak ders işlemek & 3 & K6, K10, K15 \\
çok zevkli & & \\
Sinıf yönetiminde sıkıntı yaşamıyorum & 1 & K10 \\
Laboratuvar ortamı yetersiz & 1 & K18 \\
Zaman problemi yaşanıyor & 1 & K12 \\
\hline
\end{tabular}


Elde edilen veriler neticesinde 10 katılımcı öğrencilerin deney ve laboratuvar kültürüne sahip olmadıklarını, 9 katılımcı ise sınıf mevcudundan ötürü sınıf kontrolünde zorluk yaşadıklarını belirtmişlerdir. Her iki nedenden de ötürü 7 katılımcı rehberliğe dayalı deney yapıldığını bildirmiştir. K13, öğrenciler deney ve laboratuvar kültürüne sahip olmamasını ve sınıf mevcudundan kaynaklı sorunları şu sözleri ile açıklamaktadır: "Simffların kalabalık olması, öğrencilerin bu konuda bilinçli olmaması, öğrencilerin güvenlik tedbirlerinden haberdar olmaması ve dikkat etmemeleri, öğrenciler laboratuvar kültürüne sahip olamadan modern tekniklere dayah deney kültürüne geçiş yapamamalarına neden olmakta". K3 ise rehberliğe dayalı deney yaptıklarını şu şekilde aktarmaktadır: "Öğrenciler laboratuvar bir derslik değil de serbest hareket edilen bir ortam olarak görüyor. Bundan dolayı rehberliğe dayalı bir yol izleniyor".

Öğrencilerin fen öğretiminde laboratuvar kullanırken araştırmacı- sorgulayıcı yaklaşıma uygun kazanım gerçekleştirme durumları Tablo 14'te verilmiştir.

\section{Tablo 14.}

Öğrencilerin Rehberliğe Dayalı Araştırmacı Sorgulayıcı, Açık Uçlu Sorgulayıcı Yaklaşıma Uygun Hareket Edebilme Durumu

\begin{tabular}{llll}
\hline Kodlar & f & \multicolumn{1}{c}{ Katılımcı } \\
\hline Kısmen uygulanmaktadır & 4 & K7, K10, K12, K13 \\
Öğrenciler daha çok rehberliğe dayalı araştırmacı yaklaşıma uygun & 3 & K2, K6, K20 \\
hareket etmektedir & 3 & K1, K4, K16 \\
Sorgulayıcı ve açık uçlu yaklaşıma uygun hareket eden öğrenci az sayıda & 3 & K1, K15 \\
Laboratuvara merak ettikleri için ilgi göstermektedirler & 2 & K5, K20 \\
7-8 de açık uçlu sorgulayııı yaklaşım uygulanamamaktadır & 2 & K8, K14 \\
Öğrenci seviyesine göre değişmektedir & 2 & K17, K18 \\
Seviyesi yüksek öğrenciler daha sorgulayıcı ve araştırmacı davranıyor & 1 & K3 \\
Öğretmen laboratuvarda daha aktif & 1 & K4 \\
Bazı öğrencileri araştırmak yerine bilgiye doğrudan ulaşmayı bekliyor & 1 & K3 \\
Hayır, bu yaklaşımlara uygun hareket etmiyorlar & 1 & K9 \\
Hayır, uygulanmamaktadır & 1 & K11 \\
Öğrencilerimde laboratuvar ortamını kullanmada yeterli oranda & & \\
özgüven duymaktadır & 1 & K19 \\
Tehlikeli malzemeler olduğu için bazı deneylerde bu yöntemler & 1 & K20 \\
uygulanamamaktadır & & \\
5. 6. Sınıflarda rehberliğe dayalı öğretim gerçekleştiriliyor & &
\end{tabular}

Katılımcıların görüşlerine göre elde edilen bazı farklı cevaplar şu şekildedir. K20'nin soruya ilişkin yorumları "5. 6. Sinıflarda rehberliğe dayalı öğretim gerçekleştiriliyor fakat 7. ve 8. 
sınıflarda açık uçlu, sorgulayıcı yaklaşım uygulanamıyor. Çünkü öğrenciler sürekli bir rehber eşliğinde yapmak istiyor yoksa deney ilerlemiyor. Bu yöntem öğrencinin donanım ve kapasitesine de bağll. Aynı zamanda sorgulayıcr yöntemin uygulanabilmesi için zaman yeterli değil. Ders bitse de deney hala devam ediyor durumun sonuçlanmaması öğrencinin bocalamasına neden oluyor" şeklindedir. K4 ise görüşlerini şu şekilde aktarmaktadır: "Bir kısmı deneyin sonuçların mantık yürüterek yorumlayabiliyor. Yeterli bilgiye sahip olmasa da deneyin avantajıyla doğru sonuca ulaşabiliyor. Diğger bir kısım ise araştırmak yerine bilgiye doğrudan ulaşmayı bekliyor ve başarısız oluyor." K1 ise laboratuvar içi genel görüşünü şu şekilde aktarmaktadır: "Laboratuvar sadece merak ettikleri için ilgi göstermekteler. Sorgulayıcı ve açık uçlu yaklaşıma uygun hareket eden öğrenci sayısı az".

Çalışmanın bir başka kapsamında yönetmelikler ile öğretmenlerin motivasyonu arasındaki ilişki Tablo $15^{\prime}$ de sunulmuştur.

Tablo 15.

Yönetmelikler ile Laboratuvar Kullanımında Öğretmen Motivasyonunu Arttırabilecek Teşvikler

\begin{tabular}{|c|c|c|}
\hline Kodlar & $\mathbf{f}$ & Katılımcı \\
\hline Laboratuvar dersi konulabilir & 7 & $\mathrm{~K} 3, \mathrm{~K} 4, \mathrm{~K} 8, \mathrm{~K} 9, \mathrm{~K} 13, \mathrm{~K} 15, \mathrm{~K} 20$ \\
\hline Öğretim ortamlarında iyileştirmeler yapılmalı & 4 & $\mathrm{~K} 10, \mathrm{~K} 12, \mathrm{~K} 13, \mathrm{~K} 18$ \\
\hline Ek ücret verilebilir & 4 & $\mathrm{~K} 5, \mathrm{~K} 9, \mathrm{~K} 14, \mathrm{~K} 20$ \\
\hline Eğitim verilebilir & 3 & $\mathrm{~K} 1, \mathrm{~K} 3, \mathrm{~K} 4$ \\
\hline $\begin{array}{l}\text { Ek puan, taktir, teşekkür vb. teşviklerin verilmesi gerekliliğini } \\
\text { savunuyorum }\end{array}$ & 3 & $\mathrm{~K} 14, \mathrm{~K} 16, \mathrm{~K} 20$ \\
\hline Fen bilimleri ders saati arttırılabilir & 2 & K3, K6 \\
\hline Öğrenci sayıları laboratuvar ortamlarına göre ayarlanmalı & 2 & K12, K18 \\
\hline Fikrim yok & 2 & K17, K19 \\
\hline $\begin{array}{l}\text { Laboratuvar için asistan ya da çift öğretmen uygulaması } \\
\text { olabilir }\end{array}$ & 1 & K7 \\
\hline Öğretmen yeterlilikleri teşvik edilebilir & 1 & K2 \\
\hline Yönetmeliklerin etkisi olacağını zannetmiyorum & 1 & $\mathrm{~K} 2$ \\
\hline $\begin{array}{l}\text { Laboratuvar konusunda bütün sorumluluk öğretmene } \\
\text { verilmesi gerekir }\end{array}$ & 1 & K11 \\
\hline
\end{tabular}

Elde edilen verilere göre genel ortak görüşün (7 katılımcı) laboratuvar için ayrı ek ders konulmasının gerekliliğidir. 4 katılımcı ise öğretim ortamlarında iyileştirmelerin yapılmasının gerekliliğinden bahsetmiştir. Bir başka 4 katılımı ise laboratuvar kullanımının teşvik edilmesi amacı ile ek ücret verilmesinden bahsetmiştir. Laboratuvar ek derslerinin konulması konusunda K13 ve K4'ün görüşleri sırasıyla şu şekildedir: "Laboratuvar dersi olarak 1 saat ekleme yapılabilir. Laboratuvarlar modern araç gereçlerle donatılabilir."; "Laboratuvar dersleri eklenebilir. Fen bilimleri 
öğretmenlerine Laboratuvar dersleri ile ilgili alternatif öğretim yöntem teknikleri seminerleri verilebilir". K9 ek ücretlerin öğretmen motivasyonlarına arttırıcı etki yapacağını "Yapılan deneyler için ek ders düzenlenmeli ve Laboratuvar ücreti alınmal. Yıpranma payı da olmalı." şeklinde cümleleri ile aktarmaktadır.

Çalışmada okul yönetiminin genel olarak fen laboratuvarı ve fen öğretmenine yaklaşımı incelenmiş ve Tablo $16^{\prime}$ da verilmiştir.

Tablo 16.

Okul Yönetiminin Fen Laboratuvarlarında Fen Öğretimine Karşı Tutumları

\begin{tabular}{lll}
\hline Kodlar & f & \multicolumn{1}{c}{ Katılımc1 } \\
\hline $\begin{array}{l}\text { Okul yönetimi gerekli özeni gösterir, motive edici ve sorun } \\
\text { çözmeye yöneliktir }\end{array}$ & 16 & $\begin{array}{l}\mathrm{K} 1, \mathrm{~K} 3, \mathrm{~K} 4, \mathrm{~K} 5, \mathrm{~K} 6, \mathrm{~K} 13, \mathrm{~K} 8, \mathrm{~K} 14, \mathrm{~K} 15, \mathrm{~K} 16, \mathrm{~K} 17, \\
\mathrm{~K} 18, \mathrm{~K} 19\end{array}$ \\
$\begin{array}{l}\text { Yönetimin fen öğretimine tutumu kötü } \\
\text { Yönetimin fen öğretimine tutumu ne iyi ne kötü }\end{array}$ & 2 & $\mathrm{~K} 2, \mathrm{~K} 11$ \\
Laboratuvardaki eksik malzemelerimiz giderilmemiştir & 2 & $\mathrm{~K} 12, \mathrm{~K} 20$ \\
Laboratuvardaki eksik malzemelerimiz tamamlanıyor & 1 & $\mathrm{~K} 11$ \\
Eksik malzemelerin öğretmenler tarafından karşılanması & 1 & $\mathrm{~K} 20$ \\
isteniyor & & \\
\hline
\end{tabular}

Elde edilen verilere göre ortak kanını (16 katılımcı) okul yönetiminin gerekli özeni gösterdiği, motive edici ve sorun çözmeye yönelik bir yaklaşımda bulunduğunu 2 katılımcının ise olumsuz yönde görüş belirttiği tespit edilmiştir. K3 idarenin tavrını şu cümleleri ile aktarmıştır: "İdarecilerimiz laboratuvar konusunda çok hassas davranıyorlar. Problemlerimize çözüm üretmeye çalışıyorlar". K10 ise yine idarenin olumlu tutumunu şu şekilde dile getirmektedir: "Okul yönetiminin fen öğretimine karşı olumlu tutum sergilediğini düşünüyorum. Bizlerin isteği doğrultusunda bizlerle işbirliği yaparak varsa mevcut aksaklıklarn gideriliyor. Mümkün olduğunca yardımcı olmaya çalışılıyor". K2 ise okul yönetiminin olumsun tutumunu şu şeklide açıklamaya çalışmaktadır: "Çok kötü, defalarca laboratuvarı üst katta istememize rağmen taşınmasını istemedi. Spor odası bile 4. Katta iken laboratuvar zemin katta. Kimyasal maddeler okula zarar verir düşüncesiyle tamamı toplanıp gönderildi (Bize sorulmadan)".

Çalışmada önemli bir durum ise laboratuvarda güvenlik sorunları karşısında öğretmenlerin tepkilerinin ne olacağı yönündedir. Bu durum Tablo 17'de ayrıntılı olarak sunulmuştur. 
Tablo 17.

Güvenlik Sorunlarında Öğretmenlerin Laboratuvar Kullanımına Yönelik Tutumları

\begin{tabular}{|c|c|c|}
\hline Kodlar & f & Katılımcı \\
\hline Güvenlik sorunu yaşarsam tedirgin hissederim ve & 11 & K1, K4, K6, K8, K9, K10, K11, \\
\hline laboratuvar kullanımını azaltırım. & 12 & K12, K14 K17, K18, K20 \\
\hline Olumsuz etkiler & 2 & K7, K19 \\
\hline Güvenlik önlemleri alırım & 2 & $\mathrm{~K} 2, \mathrm{~K} 5$ \\
\hline Güvenlik sorunları laboratuvarı kullanmamızı etkiliyor & 1 & $\mathrm{~K} 3$ \\
\hline $\begin{array}{l}\text { Ortaokul programinda bu anlamda sıkıntılı bir konu } \\
\text { bulunmuyor }\end{array}$ & 1 & K3 \\
\hline Henüz bir güvenlik sorunu yaşamadım & 1 & K4 \\
\hline $\begin{array}{l}\text { Okulumuzda herhangi bir güvenlik sorunu } \\
\text { bulunmamaktadır }\end{array}$ & 1 & K6 \\
\hline Deney sayısını azaltırdım & 1 & K13 \\
\hline $\begin{array}{l}\text { Yakın zamanda farklı bir konuda bir güvenlik sorunu olduğu } \\
\text { için daha titiz davranıyorum }\end{array}$ & 1 & K15 \\
\hline Laboratuvar güvenliğimiz oluşmuş durumda & 1 & K16 \\
\hline
\end{tabular}

Güvenlik sorunu konusunda K10 görüşlerini "Laboratuvarda güvenlik sorunu olursa endişeli ve korku içinde olurum. Kendimi rahat hissetmem." şeklinde dile getirmiştir. K4 ise "Henüz bir güvenlik sorunu yaşamadım. Ancak yaşarsam tedirgin hissederim. Laboratuvar kullanımın azaltırım" diyerek konuyla ilgili tedirginliğini aktarmaya çalışmıştır. K17'nin görüşü ise şu şekildedir: "Laboratuvarda meydana gelebilecek ya da meydana gelen güvenlik sorunlar, Laboratuvar kullanımın olumsuz etkiler. O malzemeleri kullanmak istemem."

\section{TARTIŞMA VE SONUÇ}

Çalışmada, fen bilgisi öğretmenlerinin laboratuvar kullanımına yönelik yeterlik algılarının üst düzeyde olduğu görülmektedir. Nicel analiz neticesinde elde edilen verilere göre; öğretmenler, deney sonuçlarını yorumlamada en yüksek düzeyde, laboratuvar malzemelerine ilişkin bakım, onarım bilgi ve becerisine sahip olma durumunda ise en düşük düzeyde yeterlilik yansıtmışlardır. Ölçeğe kapsamında yeterlik algısının en düşük seviyede tespit edilen madde olan malzeme bakım-onarım gibi konularda da yeterlik algısı puanı yine iyi düzeydedir. Böyük, Demir ve Erol (2010), öğretmenlerin, laboratuvarlardaki araç gereçleri yeterince tanımadıkları, kullanamadıkları ve bu araç-gereçlerin bakım ve onarım bilgisine sahip olmadıklarını araştırma sonucunda vurgulamışlardır. Ancak, karşılaşılan sorunlar ve laboratuvarların verimliliğini yansıtan kontrol listesi ve yapılan yarı-yapılandırılmış mülakatla ile elde edilen nitel veriler nicel sonuçlarla bu düzeyde yüksek bir uyum sergilememektedir. Derecelendirilmiş anketler 
üzerinden alınan veriler bazı durumlarda detayları ve derinliği yansıtamayabilir. Çalışma zaten bu durumdan dolayı karma desende planlanmıştır. Çünkü hem gözlemsel veriler hem de görüşme formundan elde edilen veriler olumlu ve olumsuz koşul ve durumları daha açık bir şekilde yansıtabilmiştir.

Çalışma grubunda yer alan öğretmenler profillerine göre cinsiyet bakımından birbirine eş değer durumdadır. Ancak kadın öğretmenlerin lehine laboratuvar kullanım yeterliği anlamlı ölçüde farklılık gösterirken, mesleki kıdeme göre bir farklılık tespit edilmemiştir. Kadın öğretmenlerin lehine olan sonuçlar ile uyumlu çalışmalar mevcuttur. Böyük, Demir ve Erol (2010) benzer şekilde; kadınların laboratuvar yöntemini uygulamada kullanılan öğretim yöntem ve tekniklerini bilme, derslerde kullanabilme, derslerde kullanmaya karşı istekli olma, basit araç gereçler geliştirme ve kullanma becerisine sahip olma ve deney sonuçlarını teorik bilgilerle bütünleştirerek yeni sonuçlar üretme yeterlik düzeylerinin daha yüksek olduğunu tespit etmişlerdir. Kakayev (2019) tez çalışmasında fen bilgisi öğretmenlerinin laboratuvar yönetimi yeterliklerinin cinsiyet değişkenine göre kadınlar lehine anlamlı olduğunu belirtmiştir. Hung (2010) sorgulamaya dayalı öğrenmenin fen başarısını ve fene karşı tutumları olumlu yönde etkilediği saptanmış olup fen başarısıyla fenne karşı tutum arasında bir ilişkinin bulunduğu ve aynı zamanda cinsiyetin (Kadın öğretmenlerin lehine) de bu faktörleri etkilediği gerçeğine ulaşılmıştır. Mesleki kıdem konusunda öğretmenler arasında önemli bir farklılık olmaması ve yüksek düzeyde yeterlik algısı fen öğretiminde laboratuvarların önemi açısından avantaj olarak görülebilir. Ekici (2009) biyoloji öğretmenlerinin laboratuvar kullanımı öz-yeterlik algılarında $\leq 10$ yıl ve daha az kıdeme sahip öğretmenler lehine anlamlı bir farklılığın olduğu saptamış ve bu durumu deneyimle ilişkilendirmiştir. Geçen süre içerisinde öğretmen yetiştirme sürecinde laboratuvar derslerinin sıklığı farklılığın ortaya çıkmaması ile ilişkilendirilebilir.

Çalışmanın ikinci bölümünde, laboratuvarlar kontrol listesi üzerinden gözlemsel verilerle analiz edilmiştir. Bu kapsamda değerlendirilen 20 öğrenme ortamının okul içerisinde fiziki konumu, öğrenci sayısı ile orantılı olarak hacmi, aydınlatma ve malzeme yeterliliği ve düzeni bakımından iyi düzeyde olduğu söylenebilir. Diğer taraftan farklı deneylere göre aydınlanmanın ayarlanamaması, elektrik/su tesisatlarının her bir deney masasına ulaşmaması, yedek malzemelere yönelik ek bir fiziki mekânın olmaması, bazı durumlarda laboratuvar ve sınıfların birlikte kullanımı gibi konular ise olumsuzluklar olarak gözlenmiştir. Bu durum; fiziki mekân bakımından laboratuvarların düzeninde olumlu bir ilerleme, ancak nitelik açısından daha fazlasına gereksinim var şeklinde değerlendirilebilir. Gözlemsel verilere göre; yangın söndürücü, ilk yardım seti, görülebilir talimatname, laboratuvar kapısında görüş paneli, iş kazası önleyici el, yüz koruyucu gözlük, eldiven gibi unsurların risk faktörleri oluşturduğu gözlenmiştir. Kimyasalların saklanma biçimi, elektrik panellerine tedbir alınması ve havalandırma 
konularında ise daha hassas tutum sergilendiği belirlenmiştir. Kontrol listesine göre öğretim programı - laboratuvar ortamı birlikteliği analiz edildiğinde; malzeme niteliği, öğrenme ortamının çalışma düzeni, öğretim programında yer alan beklentiler (fen-mühendislik-teknolojitoplum ve çevre kazanımlarına göre) doğrultusunda atölye gibi bir tasarım konusunda geliştirilmesi/yenilenmesi gerektiği tespit edilmiştir. Çünkü hem laboratuvarların hem de öğrenme ortamlarının tasarımı konusunda beklenti-değişim-alışkanlık çatışması günümüzde devam eden bir süreçtir. Gözlemsel veriler bütüncül olarak değerlendirilirse, uzun süreli bir analize göre laboratuvar ortamlarının fiziki, güvenlik ve öğretim programına uyumluluğu konusunda olumlu ilerlemeler kaydedilirken, laboratuvarlarda öğrencinin daha aktif olmasını sağlayacak öğrenme ortamının tasarımı, güvenliği ve malzeme niteliği konularında gelişmelere ihtiyaç olduğu değerlendirmesi yapılabilir (Çelik, 2018). Fen laboratuvarlarına ilişkin yeni tasarımlar incelendiğinde, atölye kültüründe düşünme ve sorgulama becerilerinin ön planda olduğunu göstermektedir (Veloso ve Marques, 2017). Fen laboratuvarları statik olarak düzenlenen yapılardan öğrenme planına göre hareket edilebilen, ayrıştırılabilen, teknoloji ile uyumlu bir mimari ile değişime hazır olmalıdır (Gulson ve Symes, 2007). Fen Bilgisi öğretmenlerinin lanoratuvar yeterlik algısı nicel veriler doğrultusunda iyi düzeyde tespit edilmiştir. Bu laboratuvarların etkin kullanımı noktasında avantajlar sağlayabilir. Bununla birlikte gözlemsel veriler doğrultusunda laboratuvarların öğrenciyi daha aktif kılacak doğrultuda atölye bakış açısını yansıtan öğretim tasarımına dönüştürülmesi ile verimliliğin daha da artması olası bir sonuç görülebilir.

Araştırmanın son bölümünde ise laboratuvarların durumu ve kullanımında olası sorunlar, görüşme formu üzerinden öğretmenlere sorulmuştur. Öğretmenlerden gelen dönütler kapsamında okulların çoğunluğunda laboratuvar bulunduğu ve öğretmenlerin bir kısmı hariç diğerlerinin laboratuvarı aktif olarak kullandıkları belirlenmiştir. Öğretmenlerin büyük bir kısmı laboratuvar kullanma konusunda kendilerini yeterli gördüklerini ve öğrenmenin kalıcı olabilmesi açısından laboratuvar kullanımının önemli olduğunu dile getirmişlerdir. Çalışmalarda, laboratuvarın öğrencinin derse olan ilgisini arttırdığı, öğretmen ile öğrenci arasındaki etkileşime katkı sağladığı (Şen, Yılmaz ve Erdoğan, 2016; Yener, Köklü, Yamaç ve Yalçın, 2020) ve yaratıcılık gibi düşünme becerilerini desteklediği (Çelik, Çakır ve Katrancı, 2017; Karamustafaoğlu ve Yaman, 2006) belirlenmiştir. Bu konuda araştırmalar, sınıf içi öğrenme ortamı ile öğrencilerin bilişsel ve duyuşsal çıktıları arasında pozitif ve anlamlı bir ilişki olduğunu ortaya koymuştur (Hofstein ve Lunetta, 2004).

Diğer taraftan laboratuvarların yetersiz olması durumu, fiziki bina içerinde konumu itibari ile erşime bağlı zaman kaybı, öğretim programındaki kazanımın içeriğine ve sınıf yönetimine bağlı olarak malzemelerin sınıfa taşındığı veya kullanılmadığı da tespit edilmiştir. 
Karaca, Uluçınar ve Cansaran (2006), çalışmalarında araştırma grubunun yarıya yakınının laboratuvardan yararlandıkları sonucunu belirtmişlerdir. Soğukpınar ve Gündoğdu (2020) ise çalışmalarında, bulgunun tersi olarak öğretmenlerin çoğunluğunun laboratuvarı aktif olarak kullanmak yerine sınıf ortamında deneylerini sürdürdüklerini belirtmişlerdir. Başka çalışmalarda da laboratuvarın aktif olarak kullanılmadığı sonuçları tespit edilmiştir (Böyük, Demir ve Erol, 2010).

Fen bilgisi öğretmenleri; mevcut öğretim programının uygulanabilirliği ve laboratuvardaki malzemelerin nicel yeterliliği konusunda olumlu görüşler yansıtırken, malzemelerin niteliği ve eksikliğinin giderilmesi konusunda olumsuz görüşlere sahip oldukları tespit edilmiştir. Yazıcı ve Özmen (2015), çalışmalarında öğretim programındaki etkinliklerin uygulanabilirliği konusunda bazı eksiklikler olduğunu belirtmiştir. Farklı çalışmalarda da malzeme ve laboratuvarın fiziki şartları konusunda yetersizlik olduğu belirtilmiştir (Akıncı, Uzun ve Kışoğlu 2015; Demir, Böyük ve Koç 2011; Karaca, Uluçınar ve Cansaran, 2006; Soğukpınar ve Gündoğdu 2020).

Çalışmada dikkat çeken bir başka durum, öğrencilerin deney ve laboratuvar kültürüne ve sorgulayıcı öğrenme kültürüne sahip olma konusunda eksikliklerinin olduğunun belirlenmesidir. Öğrenme kültüründe yaşanan bu aksaklıklar ve olması planlanan sayı üstünde öğrenci olması öğretmen görüşlerine göre; laboratuvar ortamında verimi düşüren sınıf yönetimi problemini ortaya çıarabilmektedir. Bununla birlikte öğretmenlerin rehberli araştırmacısorgulayıcı yaklaşımın uygulanabilirliğine daha olumlu bakarken, özellikle açık-uçlu gibi risk faktörü yüksek ve daha ileri deney kültürü gereken durumların uygulanabilirliğini olumsuz yaklaştıkları görülmüştür. Karaca vd. (2004), çalışmalarında öğrencilerin laboratuvar çalışmalarına ilgisiz olduğunu bunun nedeni olarak da öğrencilere bireysel deneme yapabilme olanağının verilememesi olabileceğini belirtmiştir. Sınıf mevcudunun fazlalığı (Ayvacı ve Durmuş, 2013; Çoruhlu, Er Nas ve Çepni, 2009; Soğukpınar ve Gündoğdu, 2020), öğrenciyi aktif kılma, malzeme yetersizliği, zaman sıkıntısı ve sınıf yönetiminde zorluklar (Fettahlıoğlu, Öztürk, Yücel Dă̆, Kartal ve Ekici, 2012) alanyazında yapılan literatür taraması sonucunda tespit edilmiştir. Bu gibi olumsuz durumlardan dolayı araştırmaya katılan öğretmenlerin bir kısmı öğretmen merkezli deney yapıldığını bildirmiştir. Pyatt ve Sims'e göre (2007), birçok pratik aktivitede, öğrencilere incelenen fenomen hakkında kendi anlayışlarını keşfetme ve oluşturma fırsatı verilmez. Bunun nedeni, çoğu fen laboratuvarı etkinliklerinin büyük ölçüde açıklayıcı ve öğretmen merkezli laboratuvar etkinlikleri olması, öğretmenlerin gözetiminde hazırlanan adımlara göre gerçekleştirilmesidir. Dolayısıyla zaman ve malzeme israfını ve yaralanma veya hasar olasılı̆̆ını en aza indirmek için, öğretmenlerin geleneksel eğitim alışkanlıklarından vazgeçmedikleri bilinmektedir. 
Öğretmenlerin yönetim ve yönetmelik beklentileri laboratuvarların kullanabilirliği konusunda önemli faktörler olarak tespit edilmiştir. Fen bilgisi öğretmenlerinin deney yapabilme konusunda yeterlikleri ve özgüvenlerinin önceki yıllara göre arttı̆̆1 söylenebilir. Bu durum öğretmen yetiştirme sürecinde daha fazla uygulamalı eğitim ve laboratuvar ders sayılarının artışı ile orantılı görülebilir. Aynı zamanda değişen öğretim programlarının öğretmenlere yüklemiş olduğu sorumluluğun yansıması olarak da değerlendirilebilir. Akdeniz ve Karamustafaoğlu (2003) araç gereç eksikliklerinin tamamlanması yanında uygulamaları yürütecek öğretmenlerin, güncel yaklaşımları kullanarak öğrencilere öğrenme sorumluluğu veren dokümanların hazırlanması ve etkinliklerin yürütülmesi konularındaki becerilerini geliştirmeleri gerektiğini işaret etmektedir. Nitekim sürecin daha verimli olarak gelişim göstermesi bakımından, öğretmenlerin uygulamalı sürekli mesleki gelişim talepleri de vardır. Okul yönetiminin fen laboratuvarı kapsamından fen öğretmenlerini desteklediği belirtilse de laboratuvarların geliştirilmesi konusunda destekleyici tutumların esirgendiği ifade edilmiştir. Yönetmelikler ile laboratuvar kullanımında öğretmen motivasyonunu arttırabilecek teşvikler konusunda elde edilen verilere göre, genel görüşün laboratuvar için ayrı ek ders, ek ücret verilmesi ya da performansa yansıtılması beklentiler arasındadır.

Önemli bir durum olarak öğretmenler olası bir güvenlik sorununda, "güvenlik sorunu yaşarsam tedirgin hissederim ve laboratuvar kullanımını azaltırım" şeklinde görüş birliğine varmıştır. Yazıcı ve Özmen (2015), ders saatinin az olması, alt yapı yetersizliği gibi durumların öğretmenlerin laboratuvar güvenliği kapsamında sorun oluşturacağını belirtmişlerdir. Aydoğdu ve Yardımcı (2013), güvenlik kapsamını öğretmenlerin kimyasal maddelerin özelliklerini tam bilmemeleri veya yanlış bilmeleri, dikkatsizlik gibi nedenlere bağlamaktadır. Laboratuvarda deneysel etkinliklerin yürütülmesi sırasında öğretmenlerin problem yaşamaları çeşitli laboratuvar kazalarını meydana getirebilir. Benzer şekilde lisans eğitiminin bir yansıması olarak atıkların bertarafı konusunda (Coşkun, 2017) ve laboratuvar güvenlik sembollerine yönelik yeterli bilgi konusunda (Aydın, Diken, Yel ve Yılmaz 2011) öğretmenler yeterli düzeyde bilgi sahibi olamayabilir. Laboratuvarlarda güvenlik açığının ya da olası risk yönetiminin paydaşı tek başına öğretmen ye da yönetim değildir. Laboratuvar güvenliği konusunda yönetim üzerine düşen görevleri yerine getirse de bu çabalar çalışanlar tarafından benimsenmez ve desteklenmezse istenen sonuçlara ulaşılamaz. Bu nedenle başta öğretmen ve onun rehberliğinde öğrencilerin de kurallara uyması, makine ve ekipman hakkında yeterli bilgiye sahip olması, yapılan eğitim çalışmalarının önce kendi yararına olduğunu düşünerek kişisel gelişim ve mesleki gelişim amaçlı eğitim çalışmalarından olabildiğince yararlanmaya çalışmalıdırlar (Gürkan, 2018, Özcan ve Kaçar, 2021). 


\section{ÖNERILER}

Araştırma sonuçları değerlendirildiğinde laboratuvarın tamamının eksiklikleri giderilerek her öğrencinin anlamlı öğrenmesi ve araştırmacı yönü geliştirilebilmelidir. Laboratuvarın öğrencinin araştırmacı ve sorgulayıcı yönünü geliştirdiğinin farkına vararak önemsenmesi gerekir. Özellikle günümüzde atölye ortamında öğrenmenin planlanması gerekliliği aşikarken, fen öğretiminde laboratuvarların öğretim programı ile uyumlu birlikteliği sağlanmak zorundadır. Bu durumun hem lisans düzeyinde öğretmen yetiştirme sürecini şekillendirmesi beklenirken, aynı zamanda aktif öğretmenlik hizmetinin idamesi bakımından nitelikli ve sürekli mesleki gelişim faaliyetlerini de harekete geçirmelidir. Laboratuvar malzemelerinin yeterli veya eksikliği her okul bazında, sene başında zümre başkanının başkanlığında fen zümreleri tarafından belirlenmeli ve bu doğrultuda hareket edilmelidir. Bu doğrultuda eksikliklerin giderilmesi, fazlaların ve gereksiz malzemelerin toplanması Milli Eğitim Müdürlükleri tarafından gerçekleştirilmeli ve Milli Eğitim Müdürlükleri tarafından belirlenecek bir merkez laboratuvar oluşturulması ile fazla malzemelerin burada toplanması ve eğitim öğretim yılı boyunca bu merkezden sevkiyatının okullara sağlanması önerilebilir. Ayrıca okul yönetiminin laboratuvar ile ilgili çalışmaları yakından takip etmesi, laboratuvarları yönetmelik çerçevesinde kullanılıp yerinin belirlenmesini sağlanmalıdır. Laboratuvar deprem yönetmeliğine göre düzenlenmeli, elektrik tesisatı ile ilgili tedbirler okul yönetimince alınmalıdır. Öğretmenler laboratuvar malzemelerinin bakım, onarım ve kullanımının yanı sıra yeni yaklaşımlar ve laboratuvarı etkin kullanmaya yönelik eğitimler almalı, laboratuvarda derse başlamadan önce güvenlik tedbirleri alması önerilmektedir. Çünkü öğrencilerin mevcut laboratuvarda deneysel etkinliklerde görev ve sorumluluk alma kültürü, talimatların varlığı ve dikkat edilebilirliği olası iş kazası riskinin bir yansıması olarak öğretmenlerde kaygı oluşturabildiği gözlenmektedir.

\section{KAYNAKLAR}

Akdeniz, A.R., Azar, A., \& Çepni, S. (1999). Öğretmen adaylarının laboratuvar kullanma becerilerini geliştirmek için bir yaklaşım. III. Ulusal Fen Bilimleri Eğitimi Sempozyumu, Karadeniz Teknik Üniversitesi, Mili Eğitim Bakanlığı Yayınevi.

Akdeniz, A., \& Karamustafaoğlu, O. (2003). Fizik öğretimi uygulamalarında karşılaşılan güçlükler. Türk Eğitim Bilimleri Dergisi, 1(2), 1-11. Retrieved from: https://dergipark.org.tr/en/pub/tebd/issue/26132/275252

Akıncı, B., Uzun, N., \& Kışoğlu, M. (2015). Fen Bilimleri öğretmenlerinin meslekte karşılaştıkları problemler ve fen öğretiminde yaşadıkları zorluklar. Journal of Human Sciences, 12(1), 11891215.

Aktamış, H., Hiğde, E., \& Özden, B. (2016). Effects of the inquiry-based learning method on students' achievement, science process skills and attitudes towards science: A meta- 
analysis science. Journal of Turkish Science Education (TUSED), 13(4), 248-261. doi: 10.12973/tused.10183a

Atik, A.D., \& Doğan, Y. (2020). The investigation of pre-service elementary teachers' experimental selfefficacy and their opinions on the experiments: A mixed method study. International Journal of Education Technology and Scientific Researches, 5(12), 789-844.

Aydın, S., Diken, H.E., Yel, M., \& Yılmaz, M. (2011). Fen ve teknoloji ile biyoloji öğretmen adaylarının laboratuvar güvenliği hakkındaki bilgi düzeylerinin belirlenmesi. Gazi Ĕ̆itim Fakültesi Dergisi, 31(2), 583-604.

Aydoğdu, C., \& Yardımcı, E. (2013). İlköğretim fen laboratuvarlarında meydana gelen kazalar ve öğretmenlerin geliştirebilecekleri davranış tarzları. Hacettepe Üniversitesi Eğitim Fakültesi Dergisi, 44, 52-60.

Ayvacı, H., \& Durmuş, A. (2013). Fen ve teknoloji öğretmenlerinin mesleklerinin ilk yıllarında karşılaştıkları sorunlar ve bu sorunların yıllara göre değişimi. Atatürk Üniversitesi Kazım Karabekir Eğitim Fakültesi Dergisi, 27, 29-44.

Böyük, U., Demir, S., \& Erol, M. (2010). Fen ve teknoloji dersi öğretmenlerinin laboratuvar çalışmalarına yönelik yeterlik görüşlerinin farklı değişkenlere göre incelenmesi. TÜBAV Bilim Dergisi, 3(4), 342-349.

Branch, J.L., \& Solowan, D.G. (2003). Inquiry-based learning: The key to student success. Library skills. School Library in Canada, 22(4), 6-12.

Coşkun, M. (2017). Fen bilgisi öğretmen adaylarının laboratuvar güvenliği hakkındaki bilgi düzeyleri. Yayınlanmamış Yüksek Lisans Tezi, Gazi Üniversitesi, Ankara.

Çelik, H. (2018). Laboratuvar yaklaşımları ile fen öğretimi. O. Karamustafaoğlu, Ö. Tezel ve U Sarı (Ed.), Güncel yaklaşım ve yöntemlerle etkinlik destekli fen öğretimi (s. 240-279). Ankara: Pegem A Akademi.

Çelik, H., Katrancı, M., \& Çakır, E. (2017). Fen öğretiminde açık uçlu araştırmacı sorgulayıcı laboratuvar yaklaşımının yaratıcı düşünme becerisine etkisi. Turkish Journal of Primary Education, 2, 1-10.

Çoruhlu, T.Ş., Er Nas, S., \& Çepni, S. (2009). Fen ve Teknoloji öğretmenlerinin alternatif ölçme değerlendirme tekniklerini kullanmada karşılaştıkları problemler: Trabzon örneği. Yüzüncü Yıl Üniversitesi Eğitim Fakültesi Dergisi, 6(1), 122-141.

Demir, S., Böyük, U., \& Koç, A. (2011). Fen ve Teknoloji dersi öğretmenlerinin laboratuvar şartları ve kullanımına ilişkin görüşleri ile teknolojik yenilikleri İzleme Eğilimleri. Mersin Üniversitesi Eğitim Fakültesi Dergisi, 7(2), 66-79.

Duban, N. (2014). Sorgulamaya dayalı öğrenme yaklaşımı. Ş.S. Anagün ve N. Duba, (ED.), Fen bilimleri öğretimi (s. 221-240) içinde. Ankara: Anı Yayıncılık. 
Ekici, G. (2009). Biyoloji öğretmenlerinin laboratuar kullanımı öz-yeterlik algılarının incelenmesi. Ahi Evran Üniversitesi Kırşehir Eğitim Fakültesi Dergisi, 10(3), 25-35.

Fettahlığlu, P., Öztürk, N., Yücel Dağ, M., Kartal, T., \& Ekici, G. (2012). Evaluating science teachers' views about dimensions of teaching programme according to their levels of selfefficacy beliefs. Necatibey Faculty of Education Electronic Journal of Science and Mathematics Education, 6(2), 103-134.

Fraenkel, J.R., \& Wallen, N.E. (2006). How to design and evaluate research in education (6th Ed.). New York, NY: McGraw-Hill.

Gulson, N., \& Symes, C. (2007). Theories of education: Policy and geography matters. New York: Routledge/Taylor \& Francis.

Güneş, M., Dilek, N., Topal, N., \& Can, N. (2013). Fen ve teknoloji dersinde laboratuar kullanımına yönelik öğretmen ve öğrenci değerlendirmeleri. Dicle Üniversitesi Ziya Gökalp Eğitim Fakültesi Dergisi, 20, 1-11.

Gürkan, E. (2018). Sürdürülebilir laboratuvar güvenliği kültürü. Celal Bayar Üniversitesi Sağllk Bilimleri Enstitüsü Dergisi, 5(4), 224-230.

Hofstein, A., \& Lunetta, V.N. (2004). The laboratory in science education: Foundation for the 21st century. Science Education, 88(1), 28-54.

Hung, M. (2010). What matters in inquiry-based science instruction? ERIC Digest. Retrieved February 20, 2011, from ERIC database. (ERIC Identifier: ED514026)

Jeffery, E., Nomme, K., Deane, T., Pollock, C., \& Birol, G. (2016). Investigating the role of an inquiry-based biology lab course on student attitudes and views toward science. CBE-Life Sciences Education, 15:ar61, 1-12. doi:10.1187/cbe.14-11-0203

Kakayev, K. (2019). Ortaokul fen bilimleri öğretmenlerinin laboratuvar yönetimine ilişkin yeterliliklerinin belirlenmesi. Yayınlanmamış Yüksek Lisans Tezi, Uludağ Üniversitesi, Bursa.

Karaca, A., Uluçınar, Ş., \& Cansaran, A. (2006). Fenbilgisi eğitiminde laboratuvarda karşılaşılan güçlüklerin saptanması. Milli Eğitim Dergisi, 34(170), 1-7.

Karamustafaoğlu, O., \& Yaman, S. (2006). Fen eğitiminde özel öğretim yöntemleri I-II. Ankara: Anı Yayıncilik.

Kaya, A., Çepni, S., \& Küçük, M. (2004). Fizik öğretmenlerinin laboratuvarlara yönelik hizmet içi ihtiyaçları için bir program geliştirme çalışması. Gazi Üniversitesi Kastamonu Eğitim Dergisi, 12(1), 41- 56.

Koç, R.A.Y., Okumuş, R.A.S., \& Öztürk, B. (2013). Effect of cooperative learning model on science and technology laboratory practices lesson. International Journal on New Trends in Education and Their Implications, 4(4), 42-57. 
Köseoğlu, F. \& Tümay, H. (2015). Fen eğitiminde yapılandırmacıllk ve yeni öğretim yöntemleri. Ankara: Palme Yayıncilik

Kwok, P.W. (2015, June). Science laboratory learning environments in junior secondary schools. In Asia-Pacific Forum on Science Learning and Teaching, 16(1), 1-28.

Levitt, K. (2001). An analysis of elementary teachers' beliefs regarding the teaching and learning of science. Science Education, 86, 1-22.

Merriam, S.B. (2013). Nitel araştırma desen ve uygulama için bir rehber. (Çev. Ed. S. Turan). Ankara: Nobel Akademik Yayıncılık.

Millar, R. (2004). The role of practical work in the teaching and learning of science. Commissioned paper-Committee on High School Science Laboratories: Role and Vision. Washington DC: National Academy of Sciences, 308.

Milli Eğitim Bakanlığı (MEB). (2013). İlköğretim kurumlan (ilkokullar ve ortaokullar) fen bilimleri dersi $(3,4,5,6,7$ ve 8. simıflar) öğretim programı. Milli Eğitim Bakanlığı Talim ve Terbiye Kurulu Başkanlığı. Ankara.

Milli Eğitim Bakanlığı (MEB). (2018). İlköğretim kurumları (ilkokullar ve ortaokullar) fen bilimleri dersi $(3,4,5,6,7$ ve 8. simıflar) öğretim programı. Milli Eğitim Bakanlığı Talim ve Terbiye Kurulu Başkanlığı. Ankara.

Nakiboğlu, C., \& Sarıkaya, S. (2000). Kimya öğretmenlerinin derslerinde laboratuvar kullanımına mezun oldukları programın etkisi. Kastamonu Eğitim Dergisi, 8(1), 95- 106.

Onwuegbuzie, A.J., \& Johnson, R.B. (2004). Mixed methods research. R.B. Johnson, ve L.B. Christensen (Ed.). Educational research: Quantitative, qualitative, and mixed approaches içinde (s. 408-431), Boston, MA: Allyn and Bacon. doi:10.3102/0013189x033007014.

Özcan, E., \& Kaçar, S. (2021). Fen eğitiminde laboratuvar güvenliğine yönelik çalışmaların incelenmesi. Fen Matematik Girişimcilik ve Teknoloji Eğitimi Dergisi, 4(2) , 91-99 . Retrieved from https://dergipark.org.tr/en/pub/fmgted/issue/62218/926924

Pyatt, K., \& Sims, R. (2007). Learner performance and attitudes in traditional versus simulated laboratory experiences. Retrieved September 23, 2008 Accessed March 22, 2008.

Soğukpınar, R., \& Gundogdu, K. (2020). Fen bilimleri dersi ve laboratuvar uygulamalarına yönelik öğrenci ve öğretmen görüşleri: bir durum çalışması. IBAD Sosyal Bilimler Dergisi, 8, 275-294. doi: 10.21733/ibad.733953.

Şen, Ş., Yılmaz, A., \& Erdoğan, Ü.I (2016). Sorgulamaya dayalı laboratuvar etkinliklerine ilişkin öğretmen adaylarının görüşleri. Elementary Education Online, 15(2), 443-468. [Online]: http://ilkogretim-online.org.tr. doi: http://dx.doi.org/10.17051/io.2016.25448.

Şimşek, P., \& Kabapınar, F. (2010). The effects of inquiry-based learning on elementary students' conceptual understanding of matter, scientific process skills and science attitudes. Procedia Social and Behavioral Sciences, 2, 1190-1194. 
Tekindal, M., \& Uğuz Arzu, Ş. (2020). Nitel araştırma yöntemi olarak fenomenolojik yaklaşımın kapsamı ve sürecine yönelik bir derleme. Ufkun Ötesi Bilim Dergisi, 20(1), 153- 182.

Uluçınar, Ş., Cansaran, A., \& Karaca, A. (2004). Fen bilimleri laboratuvar uygulamalarının değerlendirilmesi. Türk Eğitim Bilimleri Dergisi, 2(4), 465-475.

Veloso, L., \& Marques, J.S. (2017). Designing science laboratories: learning environments, school architecture and teaching and learning models. Learning Environ Res, 20, 221-248.

Wolcott, H.F. (2009). Writing up qualitative research. Thousand Oaks, CA: Sage Publications.

Yazıcı, E.K. \& Özmen, H. (2015). Fen ve teknoloji öğretim programında yer alan deney ve etkinliklerin uygulanabilirliğine ilişkin öğretmen görüşleri, Amasya Üniversitesi Eğitim Fakültesi Dergisi, 4(1), 92-117.

Yener, D., Köklü, N., Yamaç, R.Z., \& Yalçın, S. (2020). Analysis of the studies done on laboratories in Turkey. Journal of Turkish Science Education, 17(2), 162-179.

Yıldırım, A., \& Şimşek, H. (2016). Sosyal bilimlerde nitel araştırma yöntemleri. Ankara: Seçkin Yayincilik.

Yung, B.H.W. (2001). Three views of fairness in a school-based assessment scheme of practical work in biology. International Journal of Science Education, 23, 985-1005.

Etik Kurul Kararı: Bu çalışma 2018 yılında tamamlanan bir yüksek lisans tezinden üretilen çalışma olduğundan etik kurul kararı şartı gerekmemektedir. 